\title{
Migration History of the Afro-Eurasian Transition Zone, c. 300-1500: An Introduction (with a Chronological Table of Selected Events of Political and Migration History)
}

\author{
Johannes Preiser-Kapeller, Lucian Reinfandt and Yannis Stouraitis
}

When the process of compilation of this volume started in 2014, migration was without doubt already a "hot" topic. Yet, it were only the events of 2015 , ${ }^{1}$ which put migration on top of the discussion about the Euro and the economic crisis in the agenda of politicians, the wider public and the media. In this heated debate, the events of past migrations have been employed in a biased manner as arguments against a new "Völkerwanderung" destined to disintegrate Europe as it did with the (Western) Roman Empire. Thus, the present volume could be seen, among other things, also as an effort to provide a corrective to such oversimplifying recourses to the ancient and medieval period. ${ }^{2}$ It should be noted, however, that it was planned and drafted before the events.

The volume emerged from a series of papers given at the European Social Science History Conference in Vienna in April 2014 in two sessions on "Early Medieval Migrations" organized by Professors Dirk Hoerder and Johannes Koder. Their aim was to integrate the migration history of the medieval period into the wider discourse of migration studies and to include recent research. The three editors have added contributions by specialists for other periods and regions in order to cover as wide an area and a spectrum of forms of migration as possible. Still, it was not possible to cover all regions, periods and migration movements with the same weight; as one of the anonymous reviewers properly pointed out, the "work's centre of gravity is (...) between the Eastern Mediterranean region and the Tigris/Euphrates", with Africa not included in a similar way as Asia or Europe. Therefore, the following sections of the introduction aim first to provide some methodological considerations and then

1 Now even on Wikipedia called the "European migrant crisis", cf. https://en.wikipedia.org/ wiki/European_migrant_crisis. For a short overview, see Luft, Die Flüchtlingskrise.

2 Cf. also Pohl, Die Völkerwanderung. 
to contextualise the individual chapters within an overview on the wider migration history of the "Afro-Eurasian Transition Zone" during the centuries between 300 and 1500 A.D., in Western European historiographical tradition called the "medieval" ones. ${ }^{3}$

\section{Medieval Migration History and its Study}

Migration can been defined as permanent or long-term dislocation of the place of residence, both by individuals and by groups of any size. ${ }^{4}$ Earlier research on the medieval period focused on the upper end of this scale, such as the assumed mass migration of peoples during the "Völkerwanderung" of the 4th-6th centuries A.D. and its impact on the Late Roman Empire and its territorial and "cultural" integrity. 5 This approach found its basis in the Latin and Greek historiography of late antiquity, which actually described a "landslide" of "barbarians" affecting the Imperium Romanum, especially starting with the "arrival" of the Huns in $375 .{ }^{6}$ This culminated in a first shocking defeat of the Roman imperial army at Adrianople (modern-day Edirne in Turkey) in $378 .{ }^{7}$ However, scholars of the 18th-2oth centuries were equally interested in these migrating peoples as potential founding fathers of various "modern" nationstates such as France or Germany. These efforts in historiographical "nationbuilding" spread from Western Europe into Eastern Europe and beyond, creating similar discourses onto other early medieval migrations such as the one of the Slavs (in the 6th-9th centuries) or of the Magyars/Hungarians (in the 9th1oth centuries). ${ }^{8}$ Written evidence was increasingly enriched with archaeological findings, which, however, were also primarily interpreted within the framework of ancient and medieval historiography, trying to identify ethnic groups named in the sources with specific material cultures. Thereby, it was attempted to trace migration routes back beyond the horizon of the Latin and Greek sources to Scandinavia, Eastern Europe, Central Asia or - in the case of the Huns - even to East Asia, where connections were sought with ethnic labels

3 On the issue of periodization, see now Le Goff, Faut-ilvraiment découper l'histoire en tranches?

4 Harzig/Hoerder, Migration History.

5 Demandt, Der Fall Roms, pp. 467-49o; Halsall, Barbarian Migrations, pp. 10-25; Aberth, Contesting the Middle Ages, pp. 1-34.

6 Cited after Stickler, Hunnen, p. 47.

7 Stickler, Die Hunnen, p. 49.

8 Curta, Southeastern Europe in the Middle Ages, pp. $28-38$. 
from Chinese sources (such as the "Xiongnu", for the first time by Joseph de Guignes in 1756$){ }^{9}$

These attempts at grand linear narratives, aiming at "histories of origin" of modern-day peoples and their entitlements to "nation-hood" within specific geographical borders, obscured the actual complexity of archaeological and written evidence and its inconsistencies and obstreperousness against simple interpretations. When the massacres of World War II at least partly de-legitimised the nationalist history writing of the previous decades, more nuanced interpretative models gained currency. It became evident that there is almost never a one-to-one equivalence of archaeological findings and historiography, and that the latter implied a high flexibility of ethnic identities. Ethnic labels as well as individuals and groups could move from one social formation to another, and some groups not only became visible for the first time in Roman, Persian or Chinese historiography but they actually took shape on the frontiers of these imperial spheres or even on their soil. Assumptions on a fixed composition and ethnicity of these "peoples" over centuries, symbolised through colourful balls or arrows moving across maps in historical atlases, were thus rejected. Migration as such was identified as decisive for group and identity formation. Furthermore, the settlement of these groups on new territories and their interaction with long-established populations and elites were now interpreted less as the results of conquest and subjugation but of negotiations and processes of accommodation and assimilation. As Walter Pohl has summed up: "Unfortunately, we do not know much about the ethnic identities beyond the borders of the empire. (...) It is not a people (...) who wandered, but various groups that re-formed themselves after multiple breaks, and which in doing so attached themselves to (ethnic) traditions. (...) The struggles for power in the Empire required large groups whose success strengthened their ethnic cohesion". ${ }^{10}$ Similar models have then been adopted from the Late Roman case for other migration processes of the period, from 4 th -7 th century China to the Arab conquest of the 7 th-8th centuries or the Seljuq invasion into Byzantine Anatolia in the 11th century.11

The earlier research focus on early medieval phenomena of mass migration has been complemented with an attention on the mobility of smaller groups or even individuals and its potential impact on cultural change..$^{12}$ Migrations

9 Kim, The Huns; Halsall, Barbarian Migrations, pp. 10-15; Curta, Southeastern Europe in the Middle Ages, pp. 21-28.

$10 \quad$ Pohl, Die Völkerwanderung, pp. 20-39; Halsall, Barbarian Migrations, pp. 15-19.

11 Lewis, China between Empires; Tannous, The Making of the Medieval Middle East; Beihammer, Byzantium and the Emergence of Muslim-Turkish Anatolia.

12 Borgolte, "Einführung", pp. 17-18. 
could be seasonal or circular and across smaller ranges, both in "sedentary" and in "nomadic" societies, such as cases of transhumance or recurrent labour migration. "Trade diasporas" have become a special field of research. These refer to "communities of merchants living in interconnected networks among strangers", such as the Sogdians between Iran and China in the 4th-9th centuries, and diasporas in general, such as Jewish or Armenian communities or other ethnic/religious minorities. ${ }^{13}$ The impact of individual travellers such as missionaries (as in the prominent cases of Christian Irish monks migrating to mainland Europe in the 6th to 8th centuries) or members of elites (cases of marriages to foreign courts, for instance) equally has to be taken into consideration. ${ }^{14}$

Already in the 188 os, E.G. Ravenstein classified mobile individuals by distance and time into local migrants, short-journey migrants, long-journey migrants, migrants by stages and temporary migrants. His "Laws of Migration" identified economic factors as main causes of migration within a framework of "push and pull", where socio-economic or political conditions in the place of origin motivate mobility while the character of these conditions in the place of destination attracts mobility. Of course, this framework underwent several modifications since then, but core concepts are still applied today, especially within economic theories of mobility. ${ }^{15}$

A "global perspective" on mobility was developed based on the "World-System Theory" as established by Immanuel Wallerstein and as adapted by Janet AbuLughod for the "late medieval World System". A "world system" is characterised by a differentiation between highly developed core areas, less developed peripheries and semi-peripheries in between, connected via "labour supply systems", within which mobility takes place. Especially for "core centres" such as Venice, attracting work force from nearby and far away "peripheries" across the Eastern Mediterranean, the value of such an approach can be illustrated for the late medieval period (see especially the chapter of Charalampos Gasparis). ${ }^{16}$

Such a macro-perspective, however, pays little attention to the agency of individuals, while recent research on migration has very much focused on the

\footnotetext{
13 Cohen, Global Diasporas.

14 Padberg, Christianisierung im Mittelalter; Hoerder, Cultures in Contact, pp. 59-91.

15 Cf. Hahn, Historische Migrationsforschung, pp. 27, 30-32, and Schwenken, Globale Migration, pp. 70-73, with further references.

16 Abu-Lughod, Before European Hegemony; Hoerder, Cultures in Contact, pp. 28-30; Schwenken, Globale Migration, pp. 82-97. For a world-system approach to earlier periods, see Beaujard, Les mondes de l'ocean indien.
} 
interplay between "structure" and individual "agency". These concepts have been described by Robert A. McLeman as follows: "The terms structure and agency are inherently linked, but their precise definitions can vary according to the context in which they are used. In simplest terms, agency refers to the degree of freedom an individual has in choosing his or her actions, while structure refers to the societal norms, obligations, and institutions that shape and set limits on the individual's actions". ${ }^{17}$ Structure and agency are also core concepts within the "systems approach" towards migration phenomena as developed recently. ${ }^{18}$ It focuses on the interplay between socio-economic, political and spatial structures both in the "society of departure"19 and in the "receiving societies", ${ }^{20}$ which very much defined the scope of action and the actual agency of individuals and groups. Equally, it highlights the significance of social networks established and/or used by individuals to effect mobility as well as integration within the socio-economic framework in the places of destination (for such an approach see the chapter of Johannes Preiser-Kapeller). ${ }^{21}$ Moreover, Charles Tilly analysed the relevance of "solidarity networks" which "provide a setting for life at the destination, a basis for solidarity and mutual aid as well as for division and conflict" for the mobility of individuals. He emphasised, however, the potentially constraining effects of such networks through which "members of immigrant groups often exploited one another as they would not have dared to exploit the native-born"; he also made clear that "every inclusion also constitutes an exclusion".22 On the whole, migration systems have been defined as "a set of delicately balanced social and economic processes that emerged gradually over many years" in order to allow for "population movements" that had a "characteristic form, and over time (...) acquired relatively stable structure and a well-defined geographic organization" following "predictable paths". ${ }^{23}$ Among the examples discussed in the present volume, especially the various imperial formations (Roman/Byzantine, Sasanian, Arab, Mongol, Venetian, etc.) could be identified as migration systems. For their expansion and maintenance of imperial rule across Afro-Eurasia, they depended on the

\footnotetext{
17 McLeman, Climate and Human Migration, p. 27.

18 Harzig/Hoerder, Migration History, pp. 78-114; Hoerder, Cultures in Contact, pp. 15-21; Hahn, Historische Migrationsforschung, pp. 21-36; Schwenken, Globale Migration, pp. $87-91$.

19 Harzig/Hoerder, Migration History, pp. 92-98.

$20 \quad$ Harzig/Hoerder, Migration History, pp. 102-110.

21 Harzig/Hoerder, Migration History, pp. 78-80.

22 Tilly, "Transplanted Networks", pp. 90 and 92; Hahn, Historische Migrationsforschung, p. 29.

23 Cited after Schwenken, Globale Migration, p. 89.
} 
"occupational" mobility and migration of elites, troops and other populations at large, established enduring axes of mobility within their sphere of influence and thus have been described as "regimes of entanglements". ${ }^{24}$

To what extent such theoretical approaches in general can be applied on the periods and regions under consideration in the present volume of course depends on the amount and character of source evidence. ${ }^{25}$ Across all centuries, we have to deal with "the disadvantages of scanty information and virtual nonexistence of worthwhile statistics", as one of the anonymous reviewers pointed out. We are of course informed best on individuals of an elite background, "cosmopolitan nobles and their households", as Dirk Hoerder has called them, but sometimes we also encounter "itinerant administrators" and other office holders or military commanders in the service of one of the empires or polities dealt with in the following pages. The same is true for "pilgrims and clerics", not least because of the often close connection of religious function and "writtenness". The later was also relevant for "merchants and traders" who were mobile as "economically informed actors", although with some exceptions - such as the Cairo Genizah documents starting already in the late 9th century - the bulk of our evidence in this regard comes from the $13^{\text {th }}-15^{\text {th }}$ centuries. During this period, we sometimes encounter individual representatives (and individual agency) of the "rural people, labourers and servants", while before that time they are often aggregated under ethnic or socio-economic umbrella terms in the sources, and their mobility is frequently described as coerced by the state or forced due to warfare or other catastrophes. The extreme form of forced mobility is of course slavery, which will also feature prominently in some of the chapters of the present volume. Nevertheless, Dirk Hoerder has suggested keeping at least at the back of one's mind the probably often-considerable degree of "agency" of individuals within non-elite strata of societies also in those cases when it does not become visible in our sources. ${ }^{26}$ The longitudinal perspective on more than a millennium of migration history in the present volume should therefore also help to explore possibilities for individual agencies when comparing different periods and regions within the so-called "Middle Ages".

\footnotetext{
24 Schuppert, Verflochtene Staatlichkeit.

25 On this issue, see also Baker/Takeyuki, Migration and Disruptions.

26 Hoerder, Cultures in Contact, pp. 59-91.
} 


\section{An Overview of Migration History in the Afro-Eurasian Transition Zone (4th-15th Century)}

Already the original selection of papers had focused on what we called "AfroEurasian Transition Zone", the vast area between the Arctic Sea and the Indian Ocean, and the Mediterranean and Central Asia, where the three continents of the "Old World" meet. The high density of overlapping routes (of commerce, pilgrimage or other forms of mobility), of imperial as well as religious and cultural spheres, made it a most promising area for the exploration of past migration. ${ }^{27}$ In what follows, we will present a short chronological overview of the history of these migration processes from the 4 th to the $15^{\text {th }}$ century A.D., addressed to non-specialist readers in particular. ${ }^{28}$ Such a macro-perspective of necessity prioritises larger-scale migration movements and often resorts to the (especially ethnic) "umbrella terms", which often hide the actual complexity of the emergence, composition and cohesion of these groups, as discussed above. Nevertheless, the following pages allow for a glimpse at the multiplicity of mobilities across various spatial ranges within the selected period and area and provide a historical embedding of the chapters in this volume.

The two centuries after the year 375 A.D. (the "arrival" of the Huns in Eastern Europe) have been identified as the period of "Barbarian invasions" into the Roman sphere. It transformed the Western Roman Empire into a mosaic of "Germanic" kingdoms from Anglo-Saxon England via the Frankish Merovingian realms and the Visigoths in Spain to the Ostrogoths in Italy and the Vandals in North Africa. ${ }^{29}$ The latter two polities, however, were "re-conquered" in the 530 s to 55 os by the Eastern Roman Empire, which continued the imperial tradition from Constantinople, the "New Rome". Yet, large parts of Italy were again lost after 568 to the invasion of the Lombards, which was interpreted as the "last" of the Germanic migrations of Late Antiquity. ${ }^{30}$ Around the same time (and originally as allies of the Lombards), the Avars established them-

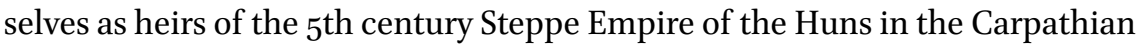
Basin. Their arrival in the steppes to the north of the Black Sea in 557, however, indicates more far-reaching political upheavals beyond Europe. Most probably (although this identification is still contested), a core element of the people

27 See also Hoerder, Cultures in Contact; Kulke, Das europäische Mittelalter.

28 For a systematic survey, see also Borgolte, Migrationen im Mittelalter. Very useful (with many illustrative maps) are equally Cunliffe, By Steppe, Desert, and Ocean, and Cunliffe, On the Ocean.

29 Pohl, Die Völkerwanderung.

3o Christie, The Lombards. 
now emerging as the Avars was constituted by groups of the Rouran, whose empire in the steppes north of China had been crashed in $55^{2}$ by a new alliance of tribes under the leadership of the Gök-Turks. ${ }^{31}$ The Turks in turn achieved dominance in the vast areas between China and the Caspian Sea, allying themselves with the Persian Empire of the Sasanians in 560 in order to conquer the realms of the Hephthalites, the last empire of the so-called "Iranian Huns". These various groups had migrated into the regions between Iran, Central Asia and India since the mid-4th century and had troubled the neighbouring Sasanians and the Gupta Empire in Northern India, whose collapse around 500 was accelerated by invasions of the "Hunas". ${ }^{32}$

In the west, the Sasanian Empire was competing with the Roman Empire across the Afro-Eurasian transition zone from the Caucasus via the Middle East to South Arabia and East Africa, also through proxy wars between regional powers allied with the one or the other imperial centre. One of these conflict zones emerged between the Kingdom of Aksum in modern-day Ethiopia and Eritrea and the Kingdom of Himyar in modern-day Yemen, especially after the former became Christianised and therefore got into closer contact with Constantinople from the 330 onwards. As George Hatke, however, demonstrates in his chapter, already the previous centuries had been characterised by intensive mobility across the Red Sea, in particular with groups from Aksum migrating to Southwest Arabia and intervening into the wars between the competing polities of the region before Himyar achieved hegemony. Warfare and migration got especially intensive again in the 6th century, with Himyar becoming a client state of Aksum for some time before Sasanian Persia intervened with an army around 570 - an intervention which led to the settlement of Iranian troops and workers in that area. ${ }^{33}$

The two predominant empires of Western Afro-Eurasia, (Eastern) Rome and (Sasanian) Persia mutually undermined their power with long and devastating wars (especially in the years $571-590$ and $602-628$ ) before they were shattered by the newly emerged community ("umma") of Islam. Under its banner, the now unified Arab tribes occupied the richest Roman provinces in Syria, Palestine and Egypt between 632 and 642 and conquered the Persian Empire up to Central Asia in its entirety by 652 . These campaigns included also large-scale movements of people into the new territories (see below).

31 Pohl, The Avars; Pohl, Die Völkerwanderung.

32 Ferrier, L'Inde des Gupta, pp. 180-206; Kulke/Rothermund, Geschichte Indiens, pp. 120-122; Baumer, The Age of the Silk Road, pp. 94-96; Alram, Das Antlitz des Fremden, pp. 89-96; Rezakhani, ReOrienting the Sasanians, pp. 97-99, 104-124; Schmiedchen, "Indien", pp. 67-69.

33 See also Hatke, Aksum and Nubia; Avanzini, By Land and by Sea; Power, The Red Sea from Byzantium to the Caliphate; Beaujard, Les mondes de l'ocean indien I, pp. 506-524. 
Moreover, in the European provinces of Eastern Rome, since the 6th century, groups of Slavs had migrated across the entire Balkans as well as into eastern Central Europe. This process intensified with the establishment of Avar power in the Carpathian Basin after 568 (see above), which additionally weakened Constantinople's control over the Danube frontier. ${ }^{34}$ Johannes Koder discusses in his chapter the Slavic immigration in the Balkans as "the most relevant population movement for the present ethnic composition of south eastern Europe", extending to the southernmost parts of the Peloponnesian peninsula. Koder mostly follows a "traditional" approach based on written and onomastic evidence, which has been used to favour an interpretation of largescale Slavic migration into the Balkans since the second half of the 6th century. In contrast, Florin Curta provides a more critical analysis of the current state of debate of migrations in the archaeology of Eastern and Southeastern Europe during the Early Middle Ages, which casts doubt on the thesis that Slavic migrations across the Danube took place at large already in the 6th century. ${ }^{35}$ Most problematic in his view is the relation between written and archaeological sources and their attempted combination in unsuitable models. ${ }^{36}$ This also extends to a field, which has become even more prominent in the last years: the use of ancient DNA and other natural scientific indicators. ${ }^{37}$ Therefore, the chapters of Koder and Curta can be read as illustrative case studies for these possible tensions between historiography and archaeology.

The situation on the Balkans was further complicated for Byzantium with the establishment of the polity of the Bulgars. Some of the steppe formations under this name making up a (short-living) empire north of the Black Sea from ca. 680 onwards occupied territories at both banks of the Lower Danube to the north of the Balkan Mountains, integrating Slavic groups into their realm. ${ }^{38}$ Since the 66os (after the collapse of the Western Turkic Khanate), the steppes to the north of the Black Sea and the Caspian Sea were dominated by a federation of various ethnic groups under the hegemony of the Khazars, whose political centre was first located to the northeast of the Caucasus in modern-day

34 Pohl, The Avars; Kardaras, Byzantium and the Avars; Gandila, Cultural Encounters; Hardt, "Slawen", pp. 171-180.

35 Cf. also Curta, The Making of the Slavs.

36 On this issue, see also Härke, "Archaeologists and Migrations"; Burmeister, "Archaeology and Migration".

37 See also Bösl, Doing Ancient DNA; Feuchter, "Über die Herausforderung der Geschichtswissenschaft durch die Genetik"; Pohl, The Genetic Challenge to Medieval History and Archaeology. For a popular introduction into this research see now Krause, Die Reise unserer Gene.

38 Ziemann, Vom Wandervolk zur Großmacht. 
Dagestan and since the 73os at the lower Volga river (with the until today unlocated capital of Itil). ${ }^{39}$

One factor intensifying these various crises in the late 6th and 7 th century may have been climate change. The "Late Antique Little Ice Age" between 536 and 660 brought about significantly cooler and more adverse climatic conditions across Afro-Eurasia. These also promoted the outbreak and diffusion of a major global plague epidemic that returned in waves between 542 and 750 especially in the west of Afro-Eurasia and possibly led to demographic depression in various areas. ${ }^{40}$ Around the time when the plague disappeared, an Arab army and Chinese troops of the Tang dynasty clashed in the Battle of Talas (in modern-day Kyrgyzstan) in July 751, thus also symbolising the new geopolitical framework of Afro-Eurasia of the 8th-9th centuries. ${ }^{41}$

The expansion and maintenance of imperial rule across Afro-Eurasia included the "occupational" mobility and migration of elites at large. ${ }^{42}$ The rapid expansion of the caliphate from the Mediterranean to North Africa and Spain as well as to Iran, Central Asia and the borders of India in the 7th and 8th centuries, for instance, was accompanied by large migrations of elites and their followers from the Arabian Peninsula to these areas, which also allowed for the spatial diffusion of Islam. The new arrivals did not represent a homogeneous mass, but consisted of different, even competing groups, mostly linked by tribal loyalties, who by no means always acted according to central planning. ${ }^{43}$ The Islamic expansion set also other ethnic groups in motion, such as the Berbers from North Africa who played a decisive role in the conquest of the Iberian Peninsula in 711 where they settled alongside the Arabs. ${ }^{44}$ The new Abbasid dynasty in the mid-8th century found supporters among regional elites in Eastern Iran and Central Asia. In the following century, several members of these groups migrated in waves as retinues of the Abbasids to Iraq and their newly founded capital of Baghdad in 762 as well as into other regions of the Caliphate. ${ }^{45}$ For the case of Iranians in 9th century Egypt, Lucian Reinfandt

39 Golden/Ben-Shammai/Róna-Tas, The World of the Khazars; Zhivkov, Khazaria.

40 Büntgen et al., "Cooling and societal change during the Late Antique Little Ice Age"; McCormick et al., "Climate Change during and after the Roman Empire".

41 See also Preiser-Kapeller, Jenseits von Rom und Karl dem Großen, pp. 38-62.

42 See also Schuppert, Verflochtene Staatlichkeit.

43 Orthmann, Stamm und Macht; Preiser-Kapeller, "Complex Processes of Migration"; Berger, "Muslimische Welt", pp. 131-135.

44 Marboe, Von Burgos nach Cuzco, pp. 57-70; Wickham, The Inheritance of Rome, pp. 338341; Sénac, Charlemagne et Mahomet, pp. 113-127; di Branco/Wolf, "Berber und Araber im Maghreb und Europa", pp. 149-159.

45 Preiser-Kapeller, "Complex Processes of Migration"; Preiser-Kapeller, Jenseits von Rom und Karl dem Großen. For the westernmost extent of this migration, see now Dold-Ghadar, Pers-Andalus. 
demonstrates how even the migration of smaller groups of administrative elites could affect local conditions and "adjacent social milieus" in the area of destination. In addition, Myriam Wissa deals with Islamic Egypt, using the Christian-Egyptian's revolt of $831 / 83^{2}$ as case study for the interaction between "indigenous" population and "newcomers" after the Arab conquest. These migrations from Central Asia, however, also had an involuntary aspect. Lutz Berger surveys the case of military slavery in the medieval Islamic world up to the 13th century. He demonstrates that "far from being an extraordinary institution", it was "just one instance of military work being left to people from the margin (socially or geographically) of a society"; during the period under consideration, especially the northern peripheries of the Islamic World from Central Asia to Caucasia served as sources of "mamlūks".46

Yet, besides the military sector, slave trade mobilized at large individuals and communities across western Afro-Eurasia. Slavic-speaking groups from Eastern and Southeastern Europe now became an important "source" of unfree labour from the 7 th century onwards. Latin texts called these groups "slavi", Greek ones "sklaviniai" and Arabic authors "saqaliba". The modern word "slave" derives most likely from these terms. The Slavs became the victims of military campaigns and slave hunts by the Frankish kingdom, the Italian maritime cities, the Bulgarian Empire, Byzantium, the Vikings, and the Khazars, as well as by competing Slavic neighbours who sold prisoners to traders from these realms. Trade routes ran in the west from the Frankish Kingdom and Italy to Spain and North Africa, in the eastern Mediterranean from the Balkans to Egypt and Syria, in the Caucasus from the Khazar Empire to Armenia and Mesopotamia and across Central Asia from Eastern Europe to eastern Iran and to Iraq. This trade over the centuries probably "mobilized" tens of thousands of people against their will over long distances, given the number of Arab silver coins partly traded in return for slaves to Eastern and Northern Europe. ${ }^{47} \mathrm{An}$ other main source of slaves was (East) Africa, whose coastal cities since the 9th century in general became focal points of mercantile and missionary activity from the Islamic world, leading to the emergence of the later so-called "Swahili". In a similar way, Islamic mobility also affected the kingdoms of West Africa to the south of the Sahara. ${ }^{48}$ The slaves becoming one of the commodities

$46 \quad$ See also Gordon, The Breaking of a Thousand Swords.

47 Rotman, Byzantine Slavery, pp. 59-76; McCormick, "New Light on the Dark Ages"; Lombard, Blütezeit des Islam, pp. 198-202; Hardt, "Slawen", pp. 177-180; Schiel, "Sklaven", pp. 255-256; Hoerder, Cultures in Contact, pp. 40-42.

48 Middleton, World of Swahili; Horton/Middleton, The Swahili; Hawkes/Wynne-Jones, "India in Africa"; Beaujard, Les mondes de l'ocean indien I, pp. 101-126. On medieval Muslim merchant communities across the Indian Ocean, see also now Beaujard, Les mondes de l'ocean indien II, pp. 48-71; Prange, Monsoon Islam, and Chaffee, The Muslim merchants of 
exchanged in these newly emerging networks were called "Zanj" in the Arabic sources (the origin of the term is unclear). In various texts, they are described as esteemed workers, especially in agriculture, but also characterized with "racist" prejudice. ${ }^{49}$ The growing number of Zanj can be derived from their mobilization in the context of various uprisings from the later 7 th century onwards. In the 9th century, many slaves from Africa worked in southern Iraq and neighbouring Khuzestan (now southwest Iran) in agriculture, especially on sugar cane plantations, or in the drainage of larger wetlands. These swamps also served as a refuge for rebels, robbers and religious deviants, and from this combination emerged a major uprising of the Zanj, who even established their own state in the years 869 to 883 , contributing to the further destabilization of Abbasid rule and thus the transformation of the geo-political world order of the 7 th- 9 th centuries. ${ }^{50}$

Youval Rotman in his chapter examines how the Byzantines resorted to "forced migration and slavery", which "were (...) two sides of the same coin". He equally demonstrates how shifting religious borders became decisive for the (re)location of areas of provenance of slaves. The Byzantine Empire, in turn, attracted the movement of Syrian and Palestinian populations from these regions after the Arab conquest of the 630s-640s, as Panagiotis Theodoropoulos surveys in his chapter in comparison with other migrations within the Caliphate. ${ }^{51} \mathrm{~A}$ similar pattern of migration can be equally observed for the Armenians, who had contributed especially to the military work force of the Eastern Roman Empire already before the Arab conquest, as Johannes Preiser-Kapeller explores in his chapter. Besides elite and military mobility, also (deliberate, coerced and forced) migrations of Armenians at large as well as commercial, occupational and religious mobility can be observed between the $5^{\text {th }}$ and the 11th century. ${ }^{52}$ For the same period, Yannis Stouraitis establishes in his chapter

Premodern China. For Muslim migrations across the Sahara, cf. Bechhaus-Gerst, "Afrika"; Fauvelle, Das Goldene Rhinozeros, pp. 6o-9o; Fauvelle, L'Afrique ancienne; Gomez, African Dominion.

49 Popovic, The Revolt of African Slaves in Iraq, pp. 14-22; Power, The Red Sea, pp. 92-95, 141-143; Heers, Les négriers en terres d'islam, pp. 27-33; Lombard, Blütezeit des Islam, pp. 202-204; Schiel, “Sklaven", pp. 253-255.

50 Popovic, The Revolt of African Slaves, pp. 22-23, 33-43; Heers, Les négriers en terres d'islam, pp. 231-240; Lombard, Blütezeit des Islam, pp. 33-34, 160-162.

$5^{1}$ Cf. also now Tannous, The Making of the Medieval Middle East.

$5^{2}$ The chapter also discusses the problem of earlier research identifying individuals as "Armenian" even generations after the migration of their forefathers and -mothers despite clear indications of their assimilation into the Byzantine elite, a phenomenon recently called by Anthony Kaldellis "The Armenian fallacy", cf. Kaldellis, Romanland, pp. $155^{-195}$. 
a typology of forced migration of groups in the geopolitical sphere of the East Roman Empire, which was mainly a consequence of war or state coercion, and he seeks to scrutinize the conditions and realities of such movements for their participants. ${ }^{53}$

With the Varangians, a new group of migrants arrived in Byzantium in various capacities (merchants, mercenaries, but also looters) from the early 9th century onwards. They came from Scandinavia via the rivers of Eastern Europe and the Black Sea to the Bosporus. Together with Slavic groups, they founded the princedom(s) of the "Rus" in Eastern Europe that were Christianised from Constantinople after $988 .{ }^{54}$ Alongside new steppe groups, emerging in the sources as "Magyars" (in Byzantine Greek texts actually first called "Tourkoi") and as "Pechenegs" (in Byzantine Greek "Patzinakitai") and migrating along the north of the Black Sea from East to West, the Varangians contributed to a de-stabilisation of the Khazar Empire as well (whose elite in the early 9th century converted to Judaism, probably under the influence of itinerant Jewish merchants as described in Arab sources under the term ar-Rädhāniyya). The Khazar Empire eventually collapsed due to attacks by the Rus in the 96os. By that time, the Magyars had established themselves in the Carpathian Basin (since the 89os) and the Pechenegs to the north of the Black Sea. ${ }^{55}$ In his introductory essay, Dirk Hoerder discusses various facets and motives of mobility between Scandinavia, Eastern Europe and Byzantium from the 9th to the 15th century such as "migration", "travel", "commerce", or "cultural transfer". His methodological considerations on the enduring effects of human mobility in the long term as well as on the short-term dynamics of the networks and spatial axes of migration set the tone for the entire volume.

After the crisis of the 7 th-8th century, the Byzantine Empire recovered economically, demographically and finally also territorially in the gth-11th century. This process attracted also merchants from the growing Italian cities of Amalfi, Venice, Genoa and Pisa in increasing numbers ${ }^{56}$ as well as migrants of Syrian and Armenian backgrounds. On the other hand, Syriac- and Armenianspeaking population became subjects of Constantinople with the expansion in

53 On populations transfers in the Byzantine Empire, see also Ditten, Ethnische Verschiebungen.

54 Scheel, Skandinavien und Byzanz; Raffensperger, Reimagining Europe.

55 Zhivkov, Khazaria; Bowlus, The Battle of Lechfeld; Pálóczi-Horváth, Pechenegs, Cumans, Iasians; Róna-Tas, Hungarians and Europe; Spinei, The Romanians and the Turkic Nomads; Gil, "The Radhanite Merchants".

$5^{6}$ See for instance Skinner, Medieval Amalf; Lilie, Handel und Politik. 
the East from the 96os to the 106os, as did Slavic-speaking people after the conquest of the Bulgarian Empire in the Balkans between the 970s and 1020s. ${ }^{57}$ The enlarged Byzantine Empire of the 11th century became more exposed to new large-scale migration movements, which turned into invasions of Byzantine territories. ${ }^{58}$ The remaining provinces in Southern Italy were lost to the Normans by 1071. These had originally moved as mercenaries from Normandy to the region and between 1061 and 1091, they conquered Arab-ruled Sicily which had become the target of migration from the Islamic world since the gth century. The emerging Norman Kingdom remained a threat for Byzantine territories to the east of the Adriatic until the late 12th century. ${ }^{59}$ North of the Black Sea, the nomadic confederacy of the Pechenegs disintegrated due to the advance of the Oghuz and then Cumans (or Kipchaks) which in turn mobilised Pecheneg groups against the Byzantine Danube frontier. Some of these came to an agreement with Constantinople and were settled on imperial soil (or did the same in the Kingdom of Hungary). ${ }^{60}$ The greatest threat for the Byzantine core provinces in Asia Minor, however, emerged from the East with the migration of new Turkish groups. They, partly under the leadership of the Seljuq dynasty, had been able to take over control over the former provinces of the Abbasid Caliphate in Central Asia and Eastern Iran since 1040 before capturing Baghdad itself in $1055 .{ }^{61}$ The decisive moment for their advance into Anatolia is traditionally connected with the defeat of the Byzantine army at Manzikert in summer 1071. As Alexander Beihammer demonstrates in his chapter, however, the Byzantine frontier organisation had already been weakened long before that, whereas conflicts within the Byzantine elite after 1071 allowed for the establishment of various not only Turkish, but also Norman and Armenian power structures. In any case, Beihammer's critical review of the sources highlights the actual complex dynamics of the "loss of Anatolia", which cannot be described as one coherent process of Turkish "Landnahme. ${ }^{62}$ The resulting vulnerable situation of Byzantium contributed to the mobilisation of thousands of warriors and other migrants in Western Europe in the context of the

\footnotetext{
57 Stephenson, Byzantium's Balkan Frontier; Preiser-Kapeller, "Byzantinische Geschichte, 1025-1204".

$5^{8} \quad$ Kaldellis, Streams of Gold, Rivers of Blood.

59 Theotokis, The Norman Campaigns.

6o Meško, "Pecheneg groups in the Balkans", with further literature; Pálóczi-Horváth, Pechenegs, Cumans, Iasians; Spinei, The Romanians and the Turkic Nomads.

61 Peacock, The Great Seljuk Empire. For possible climatic factors in these migrations from the steppe cf. Ellenblum, The Collapse of the Eastern Mediterranean, and (for a more critical view) Preiser-Kapeller, "A Collapse of the Eastern Mediterranean?".

62 See also Beihammer, Byzantium and the Emergence of Muslim-Turkish Anatolia.
} 
Crusading movement, initiated by the Papacy in 1095. From the beginning, Constantinople viewed the arrivals from the West as potential allies but also as a threat, especially due to the participation of the Normans from Southern Italy in the First Crusade. This first "armed pilgrimage" was conducive for the Byzantine recovery of territories in the western and southern coastline of Asia Minor, but the breach of agreement between the Byzantine emperor and the Crusaders resulted in the latter establishing a series of independent princedoms along the Levantine coast after the conquest of Jerusalem in 1099. The so-called Crusader States attracted the merchants of the Italian cities and settlers from Western Europe. They followed a similar pattern of "conquest and colonisation", as Robert Bartlett has called it, along the fringes of "Latin Europe" from the Iberian Peninsula to the Elbe (including the "German" settlement in Central and Eastern Europe) and from Ireland to Sicily between the 11th and 13th century. In contrast, Muslim populations from these regions were forced to abandon them and migrate to other parts of the Islamic world. ${ }^{63}$ Overall, the 12th century was characterised by a significant increase of "Latin" presence in former and current Byzantine territories and the Eastern Mediterranean. Domestic political turmoil, alongside a series of military campaigns which either caused damage to Byzantine territories (for instance the Third Crusade, $1189 / 1190$ ) or were aimed at conquering them (for instance the Norman conquest of Thessaloniki, 1185), resulted in "anti-Latin" assaults especially in Constantinople in 1170 and 1182. Against this background, inner-dynastic conflicts in 1203 caused the diversion of the Fourth Crusade towards Constantinople, which ended with the conquest and looting of the city by the Venetians and the Crusaders in April 1204. ${ }^{64}$

The year 1204 (despite the Byzantine "re-conquest" of Constantinople in 1261) marked the end of the politically united and centralized East Roman world. The same period saw the end of the (competing) Islamic Caliphates of the Abbasids (with the Mongol conquest of Baghdad in 1258) and the Fatimids in Egypt and Syria (with the downfall of the dynasty in Cairo in 1171). Instead, the Mongol expansion during the 13th century resulted in the establishment of the new large-scale imperial formations of the Golden Horde in Eastern Europe and Central Asia, and the Ilkhanids in Iran, Iraq and Anatolia. The complete conquest of all core regions of the Eastern Islamic World by the Ilkhanids was prevented by the Mamlūk Sultanate. The latter was a regime of warriorslaves mostly stemming from the Black Sea and the Caucasus regions, who

63 Bartlett, The Making of Europe; Ellenblum, Frankish Rural Settlement; Hillenbrand, The Crusades: Islamic Perspectives; Hoerder, Cultures in Contact, pp. 45-48.

64 Preiser-Kapeller, "Byzantinische Geschichte, 1025-1204". 
took over power in Egypt and Syria in 1250/1252. The increased influx of these slaves into Egypt in the decades before Ayyubid rule was partly caused by the turmoil created in their regions of origins (especially the areas of the Kipchaks) due to the Mongol invasions. Cuman/Kipchak groups also settled in Hungary as well as in the Balkans and in (at that time still Byzantine) Western Asia Minor after agreements with the rulers of these areas in the 1230 s and 1240 . Some of them, as other speakers of Turkish languages before and after, were even integrated into the Byzantine elite through baptism. ${ }^{65}$

Thus, even before their more permanent conquests in the Middle East and Eastern Europe, the campaigns of Genghis Khan and his successors provoked large-scale movements of displaced populations and troops within these areas. A telling example is the last Shāh of the Khwārazm-Empire in Eastern Iran and Central Asia, Jalāl al-Dīn, who after his defeat against the Mongols in 1221 plagued the Middle East and Caucasia with the remains of his original retinue and new followers in the search for a new realm until his death in 1231. The Ayyubid Sultan of Egypt, who used them to reconquer Jerusalem from the Crusaders in 1244, later hired parts of his troops. Around that time, the Mongols had already conquered larger parts of Eastern Europe and advanced into the core provinces of the former Abbasid Caliphate, where they captured Baghdad in $1258 .{ }^{66}$ Besides the displacements caused by their wars, the Mongols like other empires before them resorted to the relocation of troops recruited in the conquered areas and the resettlement of population at large, which acquired a new "trans-Eurasian" dimension due the immense extent of their realm. Thousands of soldiers from Russia and the Alans, who had lived north of the Caucasus and of the Black Sea, took part in the Mongol conquest of China and served in the armies of the Yuan dynasty there until the end of Mongol rule in 1368. In addition, Russian peasants and skilled workers from Eastern Europe (including German miners from Transylvania, for instance) were transferred into the Steppes of Central Asia. ${ }^{67}$ In the other direction, thousands of Oirats warriors with the families from the upper Yenissei region (together with Chinese artillerymen) took part in the Mongol conquest of Persia and Iraq and settled their. In 1296, reportedly 10,000 of them defected to the Mamlüks in the aftermath of domestic struggles in the Ilkhanate. They were settled as a welcome reinforcement at the Mediterranean coast of the Palestinian province. As Thomas T. Allsen summed up, the Mongol rulers as "herders of human beings" brought

65 Korobeinikov, "A broken mirror”; Halperin, "The Kipchak connection”; Loiseau, Les Mamelouks; Vásáry, Cumans and Tatars; Shukurov, The Byzantine Turks.

66 Jackson, The Mongols and the Islamic World; Amitai-Preiss, Mongols and Mamluks.

67 Reichert, Begegnungen mit China. 
"East Asian colonists to the west to repair the damage caused by their own military operations, while European and Muslim colonists were taken east as human booty to produce specialty industrial and agricultural goods", thus initiating a new "Völkerwanderung" of the 13th-14th centuries. ${ }^{68}$

At the fringes of the Mongol empires, however, large areas of Eastern Europe, Asia Minor and the Balkans were characterised by political fragmentation. At the same time, especially the Venetians and Genoese integrated the cities of the Eastern Mediterranean as hubs and nodes into their commercial networks and into the Mediterranean subsystem of the late medieval "World System".69 This contributed to the emergence of a multitude of overlapping zones of power and commerce as well as of various religious, ethnic and linguistic backgrounds. Between the 13th and the 15th century, "no other region of Europe or the Mediterranean became a cynosure of so many ethnicities in such a small place". ${ }^{70}$ The Eastern Mediterranean was the stage of intensive contacts between Mongols, Byzantines, Armenians, Turks, Persians and Arabs, Slavonic-, Albanian- and Vlach-speaking people, "Latins" or "Franks", and a large number of further ethnicities, members of which were of course also mobile across political borders; ${ }^{71}$ moreover, between Orthodox, Oriental and Western Christian Churches as well as Islam (in its various denominations) and (within the Mongol Sphere) also Buddhism. ${ }^{72}$ During that period, the first groups of people later known as "Gypsies" also appear in the records of Southeastern Europe, whom modern research since the 18th century tentatively has tried to connect with various groups originating in India. ${ }^{73}$ Beyond traditional supra-regional contacts of members of medieval religious elites and nobilities which always had crossed borders within and beyond cultural-religious frontiers, ${ }^{74}$ the increase in the number of contact zones, especially on the basis

68 Allsen, "Population Movements in Mongol Eurasia"; Beaujard, Les mondes de l'ocean indien II, pp. 145-159. On the consequences of Mongol conquest see also the contributions in Krämer/Schmidt/Singer, Historicing the "Beyond". For an illustrative individual female life story during this period, see Eastmond, Tamta's World.

69 Abu-Lughod, Before European Hegemony; Fleet, European and Islamic Trade, pp. 1-12; Hoerder, Cultures in Contact, 28-30.

$70 \quad$ Epstein, Purity Lost, pp. 110-111.

71 For some examples, cf. the contributions in Balard/Ducellier, Migrations et diasporas méditerranéennes, and Malamut/Ouerfelli, Les échanges en Méditerranée médiévale.

72 Abu-Lughod, Before European Hegemony; Fleet, European and Islamic Trade, pp. 1-12; Hoerder, Cultures in Contact, pp. 28-30.

73 Fraser, The Gypsies.

74 Cf. Hoerder, Cultures in Contact, pp. 6o-62; Preiser-Kapeller, "Networks of border zones", and for the example of the Seljuq-Byzantine border in Anatolia Ylldız, "Reconceptualizing the Seljuk-Cilician Frontier", and Ylldız, "Manuel Komnenos Mavrozomes". 
of commerce, opened paths to border-crossing also for non-aristocratic members of society. ${ }^{75}$ Commercial interests and occupational mobility contributed to the establishment of a "middle ground" beyond religious or ethnic antagonisms. As Kate Fleet stated in her study of Genoese and Ottoman trade: "money largely formed the basis of the relationship between the Genoese and the Turks and this, rather than any religious scruple, dictated relations" ${ }^{76}$ One illustrative aspect of these relations, also pertaining to labour mobility, is the use of eastern-style textiles in Europe and of western-style textiles in the Islamic world. 77 "Networks of affinities" were created based on profession and know how, for instance. One most impressive result of entangled phenomena in this regard is the emergence of the Lingua franca of Mediterranean seafaring in the late medieval and early modern period. ${ }^{78}$ The possibilities for (both deliberate and forced) migration that emerged in the Aegean imperial sphere of Venice after the Fourth Crusade in 1204, which involved individuals and groups of various ethno-linguistic, religious and cultural backgrounds with different chances of (upwards) social mobility, are analysed in the chapter of Charalampos Gasparis. He also demonstrates what kind of information on motives and modes of mobility can be retrieved from the more detailed (especially documentary) source evidence for this period, which we lack for earlier centuries (see also the discussion above). ${ }^{79}$

The medieval "World System" emerging from the Mongol expansion, however, also created the pre-conditions for its demise; the increased connectivity and mobility across Afro-Eurasia allowed for the diffusion of the plague epidemic of the Black Death from East and Central Asia into Western Eurasia in the 1340s, with all its devastating effects. Even before the outbreak of the epidemic, political instability and internecine wars had contributed to the decline of the Mongol imperial formations and their eventual downfall or fragmentation. ${ }^{80}$ The epidemic of the Black Death also motivated another wave of pogroms against the Jews. This intensified the already on-going shift of the core

\footnotetext{
75 See now Preiser-Kapeller/Mitsiou, "Mercantile and religious mobility".

76 Fleet, European and Islamic Trade, p. 141. For examples of labour mobility in this period, see Mitsiou/Preiser-Kapeller, "Moving Hands".

77 Flood, Objects of Translation, pp. 11, 61-85; Wardwell, "Panni Tartarici”; Mack, Bazaar to Piazza; Jacoby, "Silk Economics and Cross-Cultural Artistic Interaction"; Burns, Sea of Silk.

78 Kahane/Kahane/Tietze, The Lingua Franca of the Levant; Makris, Studien zur spätbyzantinischen Schiffahrt, pp. 112-117.

79 On migration into the city of Venice itself, see Ravid, "Venice and its Minorities".

8o Campbell, The Great Transition; Ciociltan, The Mongols and the Black Sea Trade; Jackson, The Mongols and the Islamic World; Jackson, The Mongols and the West; Aberth, Contesting the Middle Ages, pp. 243-315.
} 
areas of Jewish settlement of the so-called Ashkenazim from Western and Central Europe - where there had been a significant growth in the number of Jewish communities between the 1oth and the 13th century - to Eastern Central and Eastern Europe in the 14th-15th century. These regions finally became the homelands of the majority of all Jewish population until the Shoa during World War II. ${ }^{81}$

The 14th century saw equally the rise of a new imperial project with the establishment of the Ottoman dynasty, originally one of several Turkish groups who had started to conquer and migrate into Byzantine territories in Western Asia Minor due to Mongol pressure from the East since the second half of the 13th century. ${ }^{82}$ From $135^{2}$ onwards, Ottoman armies expanded into Southeastern Europe. Some of the indigenous nobilities resisted but others joined the Ottoman elite, which remained open for various ethnic and religious backgrounds. In addition, non-Muslim populations were integrated into the service of the Ottoman state since the 136 os by force via the so-called devşirme, the collection of Christian boys from conquered territories as tax who were converted to Islam and later served as Janissaries in the army or administration. ${ }^{83}$ By 1400, the Ottomans had become the pre-dominant power in Southeastern Europe and Anatolia and already laid siege to Constantinople. The city was only saved by a last outbreak of Mongol expansionism under Timur Leng. From his basis in Samarkand, he afflicted since the 136os large parts of Central Asia, Eastern Europe, India, Iran, Iraq and Anatolia, where he defeated the Ottomans near Ankara in 1402. Timur's military campaigns caused large-scale displacements of populations across the entire region from Eastern Europe to India and from Central Asia to the Aegean. ${ }^{84}$ The Ottomans, however, were able to re-establish their empire, to conquer Constantinople in 1453, and within the next 100 years to integrate all territories from the Black Sea to Egypt and from Northwest Iran to Algeria into a new Islamic Empire. This provided the framework for a new chapter of intensified migration and mobility (including the immigration of many Jews expulsed from Spain in 1492) which is beyond the scope of the present volume. ${ }^{85}$

81 Toch, The economic history of European Jews; Ben-Sasson, Geschichte des jüdischen Volkes, pp. 687-701; Hoerder, Cultures in Contact, pp. 42-44; Aberth, Contesting the Middle Ages, pp. 101-140.

82 Korobeinikov, Byzantium and the Turks.

83 Werner, Die Geburt einer Großmacht; Barkey, Empire of Difference; Kafadar, Between Two Worlds; Imber, The Ottoman Empire.

$84 \quad$ Nagel, Timur der Eroberer.

85 Hoerder, Cultures in Contact, pp. 108-117; Faroqhi, Travel and Artisans in the Ottoman Empire; Bossong, Die Sepharden. 
Despite the impressive number of forced or voluntary migrations described in the papers of this volume, we have to be aware that many extensive population movements remained below the "radar" of state authorities or the interest of official historiography. ${ }^{86}$ As an example, we may mention the long-distance migrating movements of nomadic groups who appear in various combinations and with different names in the records of neighbouring empires, such as the Chinese, then disappear from them and eventually re-appear in new composition and with new names, for instance in Roman historiography. The exact connections between these "peoples", such as the Xiongnu and the Huns in the 4th century or the Rouran and the Avars in the 6th century, as well as the "pre-history" of the Magyars before they "emerged" in Byzantine and Latin sources in the late 9 th century, remain unclear. A further example of "hidden" migrations are the movements of Bantu-speaking groups across most of Sub-Saharan Africa in the first millennia B.C.E and A.D. ${ }^{87}$ Yet, as one of the anonymous reviewers pointed out, we have to reckon not only "with the possibility of sizable movements occurring without being mentioned in our literary sources". On the other hand, "there is the possibility of migrations recorded in medieval sources which did not actually occur!" For the latter case, one may reference the medieval "stories of origin" of peoples (in Latin "origo gentis"). They were often composed centuries after the "arrival" of groups in their "predetermined homelands" and traced their emergence and migrations across long distances many centuries back to biblical or "mythical" times, when totem animals such as a hind led the Huns or later the Bulgars across the Sea of Azov, for instance. Earlier research has attempted to "extract" remnants of the "actual" events and to draw these supposed routes of migration on maps. For present-day scholars, these texts hint rather at the significance of (actual or imagined) migrations for identity-constructions now and then..$^{88}$

\section{Conclusion}

All papers in this volume point to the heterogeneity and complexity of the phenomenon of migration. They thus caution against simplistic approaches to migration processes in pre-modern times, which tend to draw moving blocks of people on historical maps (as, for instance, in the case of the "Völkerwanderung")

\footnotetext{
86 See also Borgolte, "Migrationen im Mittelalter. Ein Überblick".

87 Eggert, "The Bantu Problem"; Bechhaus-Gerst, "Afrika”; Fauvelle, Das Goldene Rhinozeros, pp. 6o-9o; Fauvelle, L'Afrique ancienne.

88 Plassmann, Origo gentis.
} 
with allegedly distinct homogenous collective identities such as "Slavs", "Muslims" etc. (even though we have unavoidably made use of such conventional "umbrella terms" in the historical outline above).

Against this background, the present volume hopes to contribute to and to motivate further research in the field of migration history beyond the modern era, by focussing on the medieval period and redirecting attention from Western Europe and the Atlantic towards the core transition zone between Africa, Asia and Europe. Moreover, it argues for an intensive and critical dialogue, in terms of both topics as well as methods, between historians, archaeologists, sociologists and natural scientists. Our aim was to avoid a recurrence of simplistic models, which only differ in the technical refinement of the underlying analytical tools or the novelty of terminology from earlier misconceptions.

TABLE 1.1 Chronological table of selected events of political and migration history

\begin{tabular}{|c|c|c|c|}
\hline Time & $\begin{array}{l}\text { Eastern- and } \\
\text { Southeastern Europe }\end{array}$ & Central and Western Asia & $\begin{array}{l}\text { North and East Africa } \\
\text { and (South) Arabia }\end{array}$ \\
\hline \multirow[t]{4}{*}{300} & $\begin{array}{l}303 \text { Start of } \\
\text { persecution of } \\
\text { Christians under } \\
\text { Diocletian }\end{array}$ & $\begin{array}{l}226 \text { Foundation of the } \\
\text { Sasanian empire in Iran } \\
\text { and the Iraq on a more } \\
\text { centralized basis than } \\
\text { the preceding Parthian } \\
\text { Empire }\end{array}$ & $\begin{array}{l}241 \text { Sasanians annex } \\
\text { the Kingdom of the } \\
\text { Hatrans; } 270-33^{\circ} \text { Rise } \\
\text { of the Kingdom of } \\
\text { Himyar in Southwest- } \\
\text { ern Arabia }\end{array}$ \\
\hline & $\begin{array}{l}313 \text { Toleration of } \\
\text { Christianity in the } \\
\text { Roman Empire (Edict } \\
\text { of Milan) }\end{array}$ & $\begin{array}{l}311 \text { Conquest of the } \\
\text { Chinese capital Luoyang } \\
\text { by troops of the Xiongnu, } \\
\text { collapse of imperial rule } \\
\text { in the north of China }\end{array}$ & $\begin{array}{l}\text { Between } 200 \text { and } 500 \\
\text { migration of Austrone- } \\
\text { sian groups from } \\
\text { Southeast Asia to } \\
\text { Madagascar }\end{array}$ \\
\hline & & $\begin{array}{l}\text { 309-379 Reign of Great } \\
\text { King Shapur II in } \\
\text { Sasanian Persia, frequent } \\
\text { wars with the Roman } \\
\text { Empire }\end{array}$ & \\
\hline & $\begin{array}{l}330 \text { Inauguration of } \\
\text { Constantinople as } \\
\text { (one) capital of the } \\
\text { Roman Empire }\end{array}$ & $\begin{array}{l}320-335 \text { Reign of } \\
\text { Chandragupta I, rise of } \\
\text { the Gupta dynasty in } \\
\text { North India }\end{array}$ & $\begin{array}{l}330 \text { Advance of troops } \\
\text { of the Kingdom of } \\
\text { Aksum (modern-day } \\
\text { Ethiopia and Eritrea) } \\
\text { into Nubia (modern- } \\
\text { day Sudan) }\end{array}$ \\
\hline
\end{tabular}


TABLE 1.1 Chronological table of selected events of political and migration history (cont.)

\begin{tabular}{|c|c|c|c|}
\hline Time & $\begin{array}{l}\text { Eastern- and } \\
\text { Southeastern Europe }\end{array}$ & Central and Western Asia & $\begin{array}{l}\text { North and East Africa } \\
\text { and (South) Arabia }\end{array}$ \\
\hline & & & 340 Conversion of King \\
\hline & & & Ezana of Aksum to \\
\hline & & & Christianity, establish- \\
\hline & & & ment of ecclesiastical \\
\hline & & & contacts with Roman \\
\hline & & & Egypt \\
\hline
\end{tabular}

350 Migration of the so-called "Iranian Huns" into Western Central Asia, establishment of the Kidarites as first dynasty, wars with the Sasanian Persian Empire 359-363 War between Rome and Sasanian Persia

375 Migration of the

Huns into Eastern Europe north of the Caucasus and Black Sea, attacks on the Alans and the Goths 378 Defeat of the Roman Emperor Valens against Gothic troops in the Battle of Adrianople; 382 Emperor Theodosius I makes Thervingian Goths settle as foederati in Thrace along the Danube 388 and 394 Hunnic troops in the service 395-398 Hunnic invasions across the of the Roman Caucasus into Roman Emperor Theodosius I; and Sasanian Persian after his death 395

\section{6-534 Northern Wei}

dynasty, patrons of

Buddhism in north

China; 390 Replacement of the Kidarite dynasty by the Alkhonites of the "Iranian Huns"
$370-375$ revolt of

Firmus in North Africa against the Roman Emperor Valentinian I
398 Defeat of Gildo's revolt in North Africa 


\section{Time Eastern- and Central and Western Asia North and East Africa Southeastern Europe and (South) Arabia}

\begin{tabular}{|c|c|c|c|}
\hline & $\begin{array}{l}\text { rules of his sons } \\
\text { Honorius in the } \\
\text { West and Arcadius } \\
\text { in the East (in } \\
\text { Constantinople) }\end{array}$ & & \\
\hline 400 & $\begin{array}{l}404 / 405 \text { and } 408 \\
\text { Hunnic raids into } \\
\text { Roman territories } \\
\text { south of the Danube }\end{array}$ & $\begin{array}{l}399-420 \text { Reign of the } \\
\text { Sasanian Great King } \\
\text { Yazdegerd I, good } \\
\text { relations with the Roman } \\
\text { Empire }\end{array}$ & \\
\hline & $\begin{array}{l}410 \text { Plunder of Rome } \\
\text { by the troops of the } \\
\text { Visigothic King Alaric }\end{array}$ & $\begin{array}{l}413 / 415 \text { Death of } \\
\text { Chandragupta II, apex of } \\
\text { the power of the Gupta } \\
\text { in North India }\end{array}$ & \\
\hline & $\begin{array}{l}422-434 \text { Reign of } \\
\text { Ruga over the Huns, } \\
\text { exerting of tributes } \\
\text { from the Roman } \\
\text { Empire }\end{array}$ & $\begin{array}{l}421-422 \text { War between } \\
\text { Rome and Sasanian } \\
\text { Persia }\end{array}$ & $\begin{array}{l}429-439 \text { Migration of } \\
\text { the Vandals into North } \\
\text { Africa, establishment } \\
\text { of their kingdom }\end{array}$ \\
\hline & $\begin{array}{l}434-453 \text { Reign of } \\
\text { Attila over the Huns, } \\
\text { exerting of increasing } \\
\text { tributes from the } \\
\text { Roman Empire }\end{array}$ & $\begin{array}{l}\text { 439-442 War between } \\
\text { Rome and Sasanian } \\
\text { Persia }\end{array}$ & $\begin{array}{l}430 \text { Augustine dies } \\
\text { during the siege of } \\
\text { Hippo by the Vandals }\end{array}$ \\
\hline & $\begin{array}{l}454 \text { Collapse of the } \\
\text { Hunnic Empire after } \\
\text { the death of Attila } \\
\text { (in 453) }\end{array}$ & $\begin{array}{l}45^{0}-45^{1} \text { Rebellion in } \\
\text { Armenia against } \\
\text { Sasanian rule }\end{array}$ & \\
\hline & $\begin{array}{l}455 \text { Plunder of Rome } \\
\text { by the Vandals }\end{array}$ & $\begin{array}{l}460 \text { First reference to a } \\
\text { westwards advance of } \\
\text { the "Avars", which causes } \\
\text { further migrations of } \\
\text { Sabirs and Oghurs } \\
\text { towards the Black Sea } \\
\text { Steppes }\end{array}$ & $\begin{array}{l}468 \text { Failure of a } \\
\text { large-scale Roman } \\
\text { offensive against the } \\
\text { Vandals }\end{array}$ \\
\hline
\end{tabular}


TABLE 1.1 Chronological table of selected events of political and migration history (cont.)

\begin{tabular}{|c|c|c|c|}
\hline Time & $\begin{array}{l}\text { Eastern- and } \\
\text { Southeastern Europe }\end{array}$ & Central and Western Asia & $\begin{array}{l}\text { North and East Africa } \\
\text { and (South) Arabia }\end{array}$ \\
\hline & $\begin{array}{l}476 \text { Deposition of the } \\
\text { last Western Roman } \\
\text { Emperor in Italy by } \\
\text { the Germanic general } \\
\text { Odoacer }\end{array}$ & $\begin{array}{l}45^{8}-5^{28} \text { Migrations of } \\
\text { "Hunas" into Northern } \\
\text { India, contributing to the } \\
\text { fragmentation of the } \\
\text { Gupta Empire }\end{array}$ & \\
\hline & $\begin{array}{l}488 \text { Migration of the } \\
\text { Ostrogoths from the } \\
\text { Balkans into Italy } \\
\text { under King Theodoric }\end{array}$ & $\begin{array}{l}484 \text { Defeat of the } \\
\text { Sasanian Great King } \\
\text { Peroz I against the } \\
\text { Hephthalites ("White } \\
\text { Huns") in the Battle of } \\
\text { Herat }\end{array}$ & \\
\hline & & $\begin{array}{l}499 \text { Great King Kavadh I } \\
\text { returns on the Sasanian } \\
\text { throne with support of } \\
\text { the Hephthalites }\end{array}$ & \\
\hline \multirow[t]{3}{*}{500} & & $\begin{array}{l}\text { 502-506 War between } \\
\text { Rome and Sasanian } \\
\text { Persia }\end{array}$ & $\begin{array}{l}500 \text { Bantu speaking } \\
\text { groups, who have } \\
\text { migrated across entire } \\
\text { Sub-Saharan Africa in } \\
\text { the } 1500 \text { year before, } \\
\text { reach modern-day } \\
\text { South Africa }\end{array}$ \\
\hline & & $\begin{array}{l}485^{-531} \text { In the reign of } \\
\text { Great King Kavadh, } \\
\text { Zoroastrianism and the } \\
\text { Sasanian aristocracy are } \\
\text { torn by Mazdak's } \\
\text { attempted "egalitarian } \\
\text { reform" }\end{array}$ & $\begin{array}{l}520-525 \text { Reign of King } \\
\text { Yusuf As'ar Yath'ar in } \\
\text { Himyar, who converts } \\
\text { to Judaism }\end{array}$ \\
\hline & $\begin{array}{l}\text { Ca. } 520 \text { First migra- } \\
\text { tions of Slavic groups } \\
\text { towards the Roman } \\
\text { Danube border }\end{array}$ & $\begin{array}{l}5^{26}-53^{2} \text { War between } \\
\text { Rome and Sasanian } \\
\text { Persia }\end{array}$ & $\begin{array}{l}523-525 \text { Invasion of } \\
\text { troops from Aksum in } \\
\text { the Kingdom of } \\
\text { Himyar; } 524 \text { martyr- } \\
\text { dom of Christians of } \\
\text { Najran }\end{array}$ \\
\hline
\end{tabular}




\begin{tabular}{|c|c|c|c|}
\hline Time & $\begin{array}{l}\text { Eastern- and } \\
\text { Southeastern Europe }\end{array}$ & Central and Western Asia & $\begin{array}{l}\text { North and East Africa } \\
\text { and (South) Arabia }\end{array}$ \\
\hline & $\begin{array}{l}535 \text { Start of the } \\
\text { (Eastern) Roman } \\
\text { campaigns for the } \\
\text { conquest of Italy from } \\
\text { the Ostrogoths (until } \\
\left.55^{2} / 553\right) ; 537 \\
\text { Dedication of Hagia } \\
\text { Sophia }\end{array}$ & $\begin{array}{l}540-562 \text { War between } \\
\text { Rome and Sasanian } \\
\text { Persia }\end{array}$ & $\begin{array}{l}533^{-} 534 \text { Conquest of } \\
\text { the Vandal Kingdom in } \\
\text { North Africa by } \\
\text { (Eastern) Roman } \\
\text { troops }\end{array}$ \\
\hline & $\begin{array}{l}541 / 542 \text { Outbreak of } \\
\text { the so-called Justini- } \\
\text { anic Plague }\end{array}$ & $\begin{array}{l}541 / 542 \text { Outbreak of the } \\
\text { so-called Justinianic } \\
\text { Plague }\end{array}$ & $\begin{array}{l}541 / 542 \text { Outbreak of } \\
\text { the so-called Justini- } \\
\text { anic Plague }\end{array}$ \\
\hline & $\begin{array}{l}557 \text { Arrival of the } \\
\text { Avars north of the } \\
\text { Caucasus }\end{array}$ & $\begin{array}{l}55^{2} \text { Collapse of the } \\
\text { Rouran Empire in } \\
\text { Mongolia, establishment } \\
\text { of the Gök Turkic Empire } \\
\text { across the Asian Steppes }\end{array}$ & $\begin{array}{l}\text { Ca. } 55^{\circ} \text { Final break of } \\
\text { the Ma'rib dam in the } \\
\text { Yemen, symbolizing } \\
\text { the decline of the } \\
\text { south Arabian } \\
\text { agricultural society and } \\
\text { the predominance of } \\
\text { pagan Bedouin } \\
\text { patterns in the Arabian } \\
\text { peninsula; after } 55^{\circ} \\
\text { Christianisation of the } \\
\text { Kingdoms of Makuria, } \\
\text { Nobatia and Alwa in } \\
\text { Nubia }\end{array}$ \\
\hline & $\begin{array}{l}568 \text { Establishment of } \\
\text { the Avar Khanate in } \\
\text { the Carpathian Basin; } \\
\text { Lombard migration } \\
\text { into Italy }\end{array}$ & $\begin{array}{l}\text { 56o Alliance between } \\
\text { Sasanian and Turks, } \\
\text { collapse of the Hephtha- } \\
\text { lite Empire }\end{array}$ & $\begin{array}{l}\text { Before } 570 \text { Aksumites } \\
\text { control Himyar and } \\
\text { attempt to invade } \\
\text { Mecca }\end{array}$ \\
\hline & $\begin{array}{l}5^{82} \text { Avar conquest of } \\
\text { the important Roman } \\
\text { frontier fortress of } \\
\text { Sirmium }\end{array}$ & $\begin{array}{l}571-590 \text { War between } \\
\text { Sasanian Persia and } \\
\text { Rome, which allies with } \\
\text { the Turks in Central Asia }\end{array}$ & $\begin{array}{l}570 \text { Sasanians occupy } \\
\text { the Yemen, expelling } \\
\text { the Aksumites, } \\
\text { migrations from Iran } \\
\text { into Southwest Arabia }\end{array}$ \\
\hline
\end{tabular}


TABLE 1.1 Chronological table of selected events of political and migration history (cont.)

$\begin{array}{llr}\text { Time } & \begin{array}{l}\text { Eastern- and } \\ \text { Southeastern Europe }\end{array} & \text { Central and Western Asia North and East Africa } \\ \text { and (South) Arabia }\end{array}$

\begin{tabular}{|c|c|c|c|}
\hline & $\begin{array}{l}586 \text { Attack of Slavic } \\
\text { groups on } \\
\text { Thessalonike }\end{array}$ & $\begin{array}{l}588 / 5^{89} \text { Unification of } \\
\text { China by Emperor Wendi } \\
\text { of the Sui Dynasty }\end{array}$ & $\begin{array}{l}\text { 580 Ghassanids, } \\
\text { Byzantine-sponsored } \\
\text { Arabs, burn Hirah, } \\
\text { capital of Sasanid- } \\
\text { sponsored Lakhmid } \\
\text { Arab kingdom in the } \\
\text { Iraq desert }\end{array}$ \\
\hline & $\begin{array}{l}590-602 \text { Campaigns } \\
\text { of the (Eastern) } \\
\text { Romans against the } \\
\text { Avars; they end with a } \\
\text { rebellion of the army } \\
\text { against Emperor } \\
\text { Maurice in } 602\end{array}$ & $\begin{array}{l}590-610 \text { Rise of the } \\
\text { Armenian general Smbat } \\
\text { Bagratuni at the court of } \\
\text { the Sasanian Great King } \\
\text { Xusro II }\end{array}$ & $\begin{array}{l}5^{82} \text { Ghassanids } \\
\text { dismissed from } \\
\text { Byzantine service; } 594 \\
\text { Conversion of the } \\
\text { Lakhmids to } \\
\text { Christianity }\end{array}$ \\
\hline \multirow[t]{4}{*}{600} & $\begin{array}{l}590-604 \text { Gregory the } \\
\text { Great, pope at Rome } \\
\text { (still under imperial } \\
\text { rule from } \\
\text { Constantinople) }\end{array}$ & $\begin{array}{l}\text { 6o2-628 War between } \\
\text { Rome and Sasanian } \\
\text { Persia }\end{array}$ & $\begin{array}{l}611 \text { Day of Dhu Qar: an } \\
\text { Arab tribal group } \\
\text { defeats a Sasanian } \\
\text { force near Hirah in the } \\
\text { Iraq desert }\end{array}$ \\
\hline & $\begin{array}{l}615 / 616 \text { and } 617 / 618 \\
\text { Attacks of Slavic and } \\
\text { Avar groups on } \\
\text { Thessalonike }\end{array}$ & $\begin{array}{l}614 \text { Conquest of } \\
\text { Jerusalem by Sasanian } \\
\text { Persian troops }\end{array}$ & $\begin{array}{l}616 / 619-630 \text { Occupa- } \\
\text { tion of Egypt by } \\
\text { Sasanian Persian } \\
\text { troops }\end{array}$ \\
\hline & $\begin{array}{l}626 \text { Avar siege of } \\
\text { Constantinople }\end{array}$ & $\begin{array}{l}622-628 \text { Heraclius } \\
\text { invades the Sasanian } \\
\text { realm via the Armenian } \\
\text { highlands }\end{array}$ & $\begin{array}{l}622 \text { Migration of } \\
\text { Muhammad and his } \\
\text { followers from Mecca } \\
\text { to Medina (the Hijra) }\end{array}$ \\
\hline & & $\begin{array}{l}629 \text { Heraclius restores } \\
\text { the True Cross to } \\
\text { Jerusalem; } 630 \text { Conquest } \\
\text { of the Eastern Turkic } \\
\text { Khanate in the Mongol } \\
\text { Steppes by troops of the } \\
\text { Chinese Tang Dynasty }\end{array}$ & $\begin{array}{l}632 \text { Integration of } \\
\text { Himyar into the } \\
\text { emerging Arab Islamic } \\
\text { Empire; Muhammad's } \\
\text { "farewell" pilgrimage, } \\
\text { Musaylimah appears as } \\
\text { prophet in Yamanah in } \\
\text { central Arabia; } \\
\text { Muhammad's death }\end{array}$ \\
\hline
\end{tabular}




\section{Time Eastern- and Central and Western Asia North and East Africa Southeastern Europe and (South) Arabia}

\begin{tabular}{|c|c|c|}
\hline $\begin{array}{l}649-650 \text { Arabs raid } \\
\text { Cyprus }\end{array}$ & $\begin{array}{l}63^{2}-65^{2} \text { Arab conquest } \\
\text { of Syria, Palestine and } \\
\text { Egypt from Rome and of } \\
\text { Sasanian Persia; the last } \\
\text { Sasanian princes find } \\
\text { refuge at the Chinese } \\
\text { court }\end{array}$ & $\begin{array}{l}641 / 642 \text { Arab conquest } \\
\text { of Egypt; migrations } \\
\text { from the Arabic } \\
\text { peninsula into Egypt } \\
\text { and other newly } \\
\text { conquered regions; } 646 \\
\text { Byzantines briefly } \\
\text { recapture Alexandria }\end{array}$ \\
\hline $\begin{array}{l}658 \text { Campaign of } \\
\text { Emperor Konstans II } \\
\text { against Slavic groups } \\
\text { on the Balkans }\end{array}$ & $\begin{array}{l}657-659 \text { Chinese } \\
\text { conquest of the Western } \\
\text { Turkic Khanate in } \\
\text { Central Asia }\end{array}$ & $\begin{array}{l}65^{2} \text { Failed Arab } \\
\text { expedition into Nubia; } \\
\text { peace treaty between } \\
\text { the Arabs and the } \\
\text { Kingdom of Makura in } \\
\text { Nubia }\end{array}$ \\
\hline $\begin{array}{l}\text { Ca. } 66 \text { o Emergence of } \\
\text { the Khazar Empire, } \\
\text { collapse of the Great } \\
\text { Bulgarian Empire } \\
\text { north of the Black Sea; } \\
667-669 \text { Arab naval } \\
\text { attacks on } \\
\text { Constantinople }\end{array}$ & $\begin{array}{l}\text { Ca. } 660 \text { Emergence of } \\
\text { the Khazar Empire north } \\
\text { of the Black and Caspian } \\
\text { Sea }\end{array}$ & $\begin{array}{l}656-661 \text { First Civil } \\
\text { War (fitnah) in the } \\
\text { Islamic Empire }\end{array}$ \\
\hline $\begin{array}{l}677 \text { Siege of Thessa- } \\
\text { lonike by Slavic groups }\end{array}$ & $\begin{array}{l}670-690 \text { Expansion of } \\
\text { the Tibetan Empire into } \\
\text { Central Asia at the cost } \\
\text { of Chinese influence }\end{array}$ & $\begin{array}{l}\text { Uqba ibn Nafi' } \\
\text { conquers Northwest } \\
\text { Africa; } 670 \text { foundation } \\
\text { of Kairouan }\end{array}$ \\
\hline $\begin{array}{l}68 \text { o Migration of parts } \\
\text { of the Bulgars to the } \\
\text { Lower Danube, } \\
\text { establishment of the } \\
\text { Bulgar Khanate }\end{array}$ & $\begin{array}{l}685 \text { First Khazar raids } \\
\text { into the Arab provinces } \\
\text { south of the Caucasus }\end{array}$ & $\begin{array}{l}\text { After } 680 \text { Relocation of } \\
\text { the political centre } \\
\text { from Aksum to the city } \\
\text { of Kubar; } 680-692 \\
\text { Second Civil War } \\
\text { (fitnah) in the Islamic } \\
\text { Empire }\end{array}$ \\
\hline $\begin{array}{l}695 \text { Exile of Emperor } \\
\text { Justinian II in the } \\
\text { Khazar Empire }\end{array}$ & $\begin{array}{l}693 \text { Defeat of Emperor } \\
\text { Justinian II against the } \\
\text { Arabs at Sebastoupolis in } \\
\text { Asia Minor }\end{array}$ & $\begin{array}{l}697-698 \text { Arab } \\
\text { conquest of Carthage } \\
\text { and further conquests } \\
\text { in North Africa }\end{array}$ \\
\hline
\end{tabular}


TABLE 1.1 Chronological table of selected events of political and migration history (cont.)

$\begin{array}{llr}\text { Time } & \begin{array}{l}\text { Eastern- and } \\ \text { Southeastern Europe }\end{array} & \text { Central and Western Asia North and East Africa } \\ & \text { and (South) Arabia }\end{array}$

\begin{tabular}{|c|c|c|c|}
\hline \multirow[t]{4}{*}{700} & $\begin{array}{l}705 \text { Emperor Justinian } \\
\text { II returns to the } \\
\text { throne in Constanti- } \\
\text { nople with the help of } \\
\text { the Bulgars }\end{array}$ & $\begin{array}{l}706 / 707 \text { Artisans sent } \\
\text { from the Byzantine } \\
\text { Empire work at the } \\
\text { building of the Great } \\
\text { Mosque in Medina }\end{array}$ & $\begin{array}{l}700 \text { Embassy from } \\
\text { Ethiopia to Patriarch } \\
\text { Simon I of Alexandria }\end{array}$ \\
\hline & $\begin{array}{l}\text { 717/718 Arab siege of } \\
\text { Constantinople; } \\
\text { Bulgar help for the } \\
\text { Byzantines }\end{array}$ & $\begin{array}{l}\text { 702-715 Establishment } \\
\text { of Arab rule in Western } \\
\text { Central Asia (Transoxa- } \\
\text { nia) and in Northwestern } \\
\text { India (Sind) }\end{array}$ & $\begin{array}{l}711 \text { Arab invasion of } \\
\text { the Visigothic Kingdom } \\
\text { on the Iberian } \\
\text { Peninsula from North } \\
\text { Africa; migrations of } \\
\text { Arabs and Berbers }\end{array}$ \\
\hline & $\begin{array}{l}720-729 \text { Pilgrimage } \\
\text { of Willibald from } \\
\text { England to Rome, } \\
\text { Jerusalem and } \\
\text { Constantinople }\end{array}$ & $\begin{array}{l}720-737 \text { Several } \\
\text { successful campaigns of } \\
\text { the Khazars against the } \\
\text { Arab provinces south of } \\
\text { the Caucasus }\end{array}$ & $\begin{array}{l}725 \text { Uprising of } \\
\text { Christian communities } \\
\text { in Egypt against Arab } \\
\text { rule and taxation }\end{array}$ \\
\hline & $\begin{array}{l}73^{2} \text { Battle of Tours } \\
\text { and Poitiers of } \\
\text { Frankish troops } \\
\text { against Arab troops } \\
\text { coming from the } \\
\text { Iberian Peninsula }\end{array}$ & $\begin{array}{l}737 \text { Defeat of the } \\
\text { Khazars against the } \\
\text { Arabs, relocation of the } \\
\text { centre of power to the } \\
\text { Lower Volga }\end{array}$ & $\begin{array}{l}73^{2-}-742 \text { Arab attacks } \\
\text { on the Kingdom of } \\
\text { Makura in Nubia }\end{array}$ \\
\hline & $\begin{array}{l}747 / 748 \text { Last great } \\
\text { outbreak of the } \\
\text { "Justinianic Plague" in } \\
\text { the Byzantine Empire }\end{array}$ & $\begin{array}{l}747-750 \text { Third Civil War } \\
\text { (fitnah) in the Islamic } \\
\text { Empire, overthrow of the } \\
\text { Caliphal dynasty of the } \\
\text { Umayyads by the } \\
\text { Abbasids, migration of } \\
\text { their followers from } \\
\text { Khurāsān to the western } \\
\text { regions of the Caliphate }\end{array}$ & $\begin{array}{l}740-742 \text { Berber } \\
\text { rebellion in North } \\
\text { Africa; } 744 \text { Baghawata } \\
\text { Berber dynasty } \\
\text { established at the } \\
\text { Atlantic coast }\end{array}$ \\
\hline & $\begin{array}{l}75^{1} \text { Conquest of } \\
\text { Byzantine Ravenna by } \\
\text { the Lombards; } 75^{6} \\
\text { Spain independent }\end{array}$ & & $\begin{array}{l}75^{\circ} \text { Advance of troops } \\
\text { from Makura up to the } \\
\text { city of Fustat in Arab } \\
\text { Egypt }\end{array}$ \\
\hline
\end{tabular}




\section{Time Eastern- and Central and Western Asia North and East Africa Southeastern Europe and (South) Arabia}

from the Abbasid

caliphate under an

Umayyad prince

756-775 Several successful campaigns

of Emperor Constan-

tine $v$ against the

Bulgars

777 Baptism of the

Bulgar Khan Telerig

after his flight to

Constantinople

792 Byzantine defeat

against the Bulgars at

Markellai
762 Foundation of

Baghdad by the new

Caliphal dynasty of the

Abbasids
757 Midrarid dynasty

(from Miknasa

Berbers) established in

Sijilmasa (modern

Morocco)

775 Temporal disrup-

tion of the canal

between the Nile and

the Red Sea at the

order of Caliph

al-Mansūr

785 Negotiations

between the Chinese

Tang Dynasty and the

Abbasid Caliph on an

alliance against Tibet

786-803 Rise of the

(originally Buddhist)

family of the Barmakids

from Balkh in Afghani-

stan at the court of

Caliph Hārūn ar-Rašīd

788-974 Shiite Idrisids

independent, establish

their capital at Fez

Since the late 8th

century increasing

trade and migration

between the Islamic

world and East Africa,

transfer of Islam and

emergence of the

Swahili culture

$800 \quad 802$ Collapse of the

Ca. 8 oo Conversion of

Avar Empire after

the elite of the Khazar

attacks by Frankish

Empire to Judaism 800-9og Reign of the

Aghlabids as de facto

independent governors

for the caliphs in North

Africa, launch attacks on Sicily, southern

Italy; Islamization of

Ifriqiyah (modern

Tunisia) 
TABLE 1.1 Chronological table of selected events of political and migration history (cont.)

$\begin{array}{llr}\text { Time } & \begin{array}{l}\text { Eastern- and } \\ \text { Southeastern Europe }\end{array} & \text { Central and Western Asia North and East Africa } \\ & \text { and (South) Arabia }\end{array}$

\begin{tabular}{|c|c|c|}
\hline $\begin{array}{l}811 \text { Defeat of the } \\
\text { Byzantine Emperor } \\
\text { Nikephoros I against } \\
\text { the Bulgars under } \\
\text { Khan Krum }\end{array}$ & $\begin{array}{l}811-813 \text { Fourth Civil } \\
\text { War (fitnah) in the } \\
\text { Islamic Empire; } 813^{-833} \\
\text { Reign of Caliph al- } \\
\text { Ma'mūn, arrival of new } \\
\text { retainers from Eastern } \\
\text { Iran and Central Asia in } \\
\text { Baghdad and the western } \\
\text { regions of the Caliphate, } \\
\text { including warrior slaves } \\
\text { (mamlūks) especially of } \\
\text { Turkic origin }\end{array}$ & $\begin{array}{l}8 \text { oo Trade contacts } \\
\text { between Arab ruled } \\
\text { North Africa and the } \\
\text { Ghana Empire; } \\
\text { migrations and transfer } \\
\text { of Islam across the } \\
\text { Sahara }\end{array}$ \\
\hline $\begin{array}{l}822 \text { Military support } \\
\text { of the Bulgars for } \\
\text { Emperor Michael II } \\
\text { against the rebel army } \\
\text { of Thomas the Slav }\end{array}$ & $\begin{array}{l}\text { 824/827 Conquest of } \\
\text { Crete by Arab emigrants } \\
\text { from Spain, who had } \\
\text { spent some years in } \\
\text { Alexandria in Egypt } \\
\text { before }\end{array}$ & $\begin{array}{l}827 \text { Beginning of the } \\
\text { Arab conquest of and } \\
\text { migration into Sicily } \\
\text { from North Africa }\end{array}$ \\
\hline $\begin{array}{l}839 \text { First reference to } \\
\text { the arrival of Varan- } \\
\text { gian Rus from } \\
\text { Scandinavia in } \\
\text { Constantinople }\end{array}$ & $\begin{array}{l}834 \text { Defection of several } \\
\text { thousand Khurramites } \\
\text { (adherents of a religious } \\
\text { rebel movement in } \\
\text { Azerbaijan) from the } \\
\text { Caliphate to the Byzan- } \\
\text { tine Empire }\end{array}$ & $\begin{array}{l}831 / 832 \text { Christian } \\
\text { revolt in Arab Egypt }\end{array}$ \\
\hline $\begin{array}{l}847-871 \text { Arab troops } \\
\text { occupy the city of Bari } \\
\text { in Southern Italy }\end{array}$ & $\begin{array}{l}\text { 847-861 Reign of the } \\
\text { Abbasid Caliph al- } \\
\text { Mutawakkil; after his } \\
\text { murder by Turkic guard } \\
\text { troops in the new capital } \\
\text { of Sāmarrā' increasing } \\
\text { political fragmentation } \\
\text { of the Arab Empire }\end{array}$ & $\begin{array}{l}847-997 \text { Reign of the } \\
\text { Yu'firid Dynasty in } \\
\text { parts of Yemen }\end{array}$ \\
\hline $\begin{array}{l}863 \text { Mission of Cyril } \\
\text { and Method to Great } \\
\text { Moravia in the }\end{array}$ & $\begin{array}{l}869 \text { to } 883 \text { Rebellion of } \\
\text { the Zanj (slaves from } \\
\text { Africa) in Abbasid Iraq }\end{array}$ & $\begin{array}{l}868-905 \text { Reign of the } \\
\text { Tulunids, a dynasty of } \\
\text { Turkic origin, as de }\end{array}$ \\
\hline
\end{tabular}




\begin{tabular}{|c|c|c|c|}
\hline Time & $\begin{array}{l}\text { Eastern- and } \\
\text { Southeastern Europe }\end{array}$ & Central and Western Asia & $\begin{array}{l}\text { North and East Africa } \\
\text { and (South) Arabia }\end{array}$ \\
\hline & $\begin{array}{l}\text { Danube region; } 864 \\
\text { Baptism of the Bulgar } \\
\text { Khan Boris with the } \\
\text { Byzantine Emperor } \\
\text { Michael III as } \\
\text { god-father }\end{array}$ & & $\begin{array}{l}\text { facto independent } \\
\text { governors in Egypt }\end{array}$ \\
\hline & $\begin{array}{l}878 \text { Baptism of } \\
\text { princes of the Serbs }\end{array}$ & $\begin{array}{l}872 \text { Resettlement of } \\
\text { members of the Pauli- } \\
\text { cian sect from Asia } \\
\text { Minor to the Balkans } \\
\text { after their defeat against } \\
\text { Byzantine troops }\end{array}$ & \\
\hline & $\begin{array}{l}881 / 882 \text { Unification } \\
\text { of the Rus princedoms } \\
\text { in Novgorod and in } \\
\text { Kiev by Oleg }\end{array}$ & $\begin{array}{l}874 \text { Rise of the Iranian } \\
\text { dynasty of the Samanids } \\
\text { in Central Asia }\end{array}$ & \\
\hline & $\begin{array}{l}\text { 896-9oo Migration of } \\
\text { the Magyars (Hungar- } \\
\text { ians) into the Carpath- } \\
\text { ian Basin under } \\
\text { pressure from the } \\
\text { Pechenegs }\end{array}$ & $\begin{array}{l}893-895 \text { War of the } \\
\text { Samanids against the } \\
\text { Oghuz, who in turn } \\
\text { attack the Pechenegs } \\
\text { together with the } \\
\text { Khazars; Pecheneg } \\
\text { migrations towards the } \\
\text { west, there exerting } \\
\text { pressure on the Magyars }\end{array}$ & $\begin{array}{l}896 \text { Emergence of the } \\
\text { Sultanate of Showa as } \\
\text { first Muslim state in } \\
\text { Ethiopia }\end{array}$ \\
\hline 900 & $\begin{array}{l}904 \text { Arab raiders } \\
\text { conquer Thessalonike }\end{array}$ & $\begin{array}{l}\text { 890-1001 Shiite } \\
\text { Hamdanids in Aleppo, } \\
\text { patronize famous } \\
\text { Muslim poets, philoso- } \\
\text { phers and scientists; } \\
\text { Samanids become } \\
\text { virtually independent in } \\
\text { Transoxania, develop } \\
\text { important administrative } \\
\text { practices, patronize } \\
\text { important Muslim poets, } \\
\text { philosophers and } \\
\text { scientists }\end{array}$ & $\begin{array}{l}909 \text { Establishment of a } \\
\text { Shiite Caliphate of the } \\
\text { Fatimids in North } \\
\text { Africa }\end{array}$ \\
\hline
\end{tabular}


TABLE 1.1 Chronological table of selected events of political and migration history (cont.)

\begin{tabular}{|c|c|c|c|}
\hline Time & $\begin{array}{l}\text { Eastern- and } \\
\text { Southeastern Europe }\end{array}$ & Central and Western Asia & $\begin{array}{l}\text { North and East Africa } \\
\text { and (South) Arabia }\end{array}$ \\
\hline & $\begin{array}{l}907-955 \text { Wide- } \\
\text { ranging raids of the } \\
\text { Magyars into Central } \\
\text { and Western Europe } \\
\text { and Italy }\end{array}$ & $\begin{array}{l}907 \text { Collapse of the Tang } \\
\text { Dynasty in China }\end{array}$ & $\begin{array}{l}914-915 \text { First attempt } \\
\text { of the Fatimids to } \\
\text { conquer Egypt }\end{array}$ \\
\hline & $\begin{array}{l}927 \text { Recognition of } \\
\text { the imperial title of } \\
\text { the Bulgarian Tsar and } \\
\text { of the establishment } \\
\text { of a Bulgarian } \\
\text { Patriarchate by the } \\
\text { Byzantine Emperor }\end{array}$ & $\begin{array}{l}922 \text { Journey of Ibn } \\
\text { Fadlan from Baghdad to } \\
\text { the Bulgars at the Volga, } \\
\text { who have accepted Islam }\end{array}$ & $\begin{array}{l}919-921 \text { Second } \\
\text { attempt of the Fatimids } \\
\text { to conquer Egypt }\end{array}$ \\
\hline
\end{tabular}

\begin{tabular}{|c|c|c|}
\hline & $\begin{array}{l}\text { 929-991 The Shiite } \\
\text { Hamdanids rule from } \\
\text { Mosul; } 936 \text { Migration of } \\
\text { parts of the Arab tribe of } \\
\text { the Banu Habib to } \\
\text { Byzantine territory }\end{array}$ & $\begin{array}{l}\text { 939-969 Reign of the } \\
\text { Ikhshidids, a dynasty of } \\
\text { Turkic origin, as de } \\
\text { facto independent } \\
\text { governors in Egypt, } \\
\text { expand into Syria }\end{array}$ \\
\hline $\begin{array}{l}948 \text { Baptism of the } \\
\text { Hungarian Prince } \\
\text { Bulscu in } \\
\text { Constantinople }\end{array}$ & $\begin{array}{l}945 \text { The Shiite Iranian } \\
\text { dynasty of the Buyids } \\
\text { becomes protector of the } \\
\text { Abbasid Caliphs in } \\
\text { Baghdad }\end{array}$ & \\
\hline $\begin{array}{l}955 \text { Baptism of the } \\
\text { Princess Olga of Kiev } \\
\text { in Constantinople }\end{array}$ & $\begin{array}{l}\text { Ca. } 950 \text { Seljuk Turks } \\
\text { move into the Bukhara } \\
\text { area and adopt Islam }\end{array}$ & \\
\hline $\begin{array}{l}963-965 \text { Conquest of } \\
\text { the Khazar cities of } \\
\text { Sarkel and of Itil by } \\
\text { Prince Sviatoslav of } \\
\text { Kiev, collapse of the } \\
\text { Khazar Empire }\end{array}$ & $\begin{array}{l}\text { 966-1045 Successive } \\
\text { annexation of various } \\
\text { Armenian princedoms } \\
\text { and kingdoms by the } \\
\text { Byzantine Empire, at the } \\
\text { same time Armenian and } \\
\text { also Syrian migrations } \\
\text { into Byzantine Central } \\
\text { and Eastern Anatolia }\end{array}$ & $\begin{array}{l}969 \text { The Fatimids } \\
\text { conquer Egypt and } \\
\text { found Cairo as their } \\
\text { new capital; relocation } \\
\text { of their retinue of } \\
\text { Arabs, Berbers and } \\
\text { military slaves of Slavic } \\
\text { and African origin to } \\
\text { Egypt }\end{array}$ \\
\hline
\end{tabular}




\begin{tabular}{|c|c|c|c|}
\hline Time & $\begin{array}{l}\text { Eastern- and } \\
\text { Southeastern Europe }\end{array}$ & Central and Western Asia & $\begin{array}{l}\text { North and East Africa } \\
\text { and (South) Arabia }\end{array}$ \\
\hline & $\begin{array}{l}970-997 \text { Reign of } \\
\text { Géza, establishment } \\
\text { of the dynasty of the } \\
\text { Arpads in Hungary }\end{array}$ & $\begin{array}{l}\text { 977-997 Rise of the } \\
\text { Turkish dynasty of the } \\
\text { Ghaznavids in Eastern } \\
\text { Iran and Western Central } \\
\text { Asia }\end{array}$ & $\begin{array}{l}975 \text { Foundation of the } \\
\text { port city of Kilwa } \\
\text { Kisiwani in Tanzania } \\
\text { by Muslim merchants } \\
\text { from Shiraz in Iran }\end{array}$ \\
\hline & $\begin{array}{l}988 \text { Baptism of Great } \\
\text { Prince Vladimir of } \\
\text { Kiev, Christianisation } \\
\text { of the Rus from } \\
\text { Constantinople; the } \\
\text { Rus mercenaries sent } \\
\text { to Constantinople } \\
\text { become the Varangian } \\
\text { Guard }\end{array}$ & $\begin{array}{l}988 \text { Peace treaty } \\
\text { between the Byzantine } \\
\text { Empire and the Fatimid } \\
\text { Caliph, demarcation of } \\
\text { spheres of influence in } \\
\text { Syria; reference to the } \\
\text { name of the Fatimid } \\
\text { Caliph in the mosque in } \\
\text { Constantinople }\end{array}$ & \\
\hline & & $\begin{array}{l}\text { 992-1124 Qarakhanids } \\
\text { in Transoxania and } \\
\text { Eastern Turkestan; } \\
\text { 997-103o Mahmud of } \\
\text { Ghaznah, expands into } \\
\text { India, Khurāsān, and } \\
\text { Transoxania }\end{array}$ & $\begin{array}{l}\text { 996-1021 Reign of the } \\
\text { Fatimid Caliph } \\
\text { al-Hākim in Egypt and } \\
\text { Palestine, constraints } \\
\text { for Christians and Jews }\end{array}$ \\
\hline 1000 & & $\begin{array}{l}1001 \text { Renewed peace } \\
\text { treaty between the } \\
\text { Byzantine Empire and } \\
\text { the Fatimid Caliph; } \\
\text { Hamdanids in Syria } \\
\text { collapse; Samanids in } \\
\text { Transoxania collapse and } \\
\text { their domains are } \\
\text { divided between } \\
\text { Mahmud of Ghaznah } \\
\text { and the Qarakhanids }\end{array}$ & $\begin{array}{l}\text { Ca. } 1000-1270 \text { Rule of } \\
\text { the Zagwe dynasty in } \\
\text { northern Ethiopia }\end{array}$ \\
\hline & $\begin{array}{l}\text { 1014-1018 Byzantine } \\
\text { conquest of the } \\
\text { Bulgarian Empire }\end{array}$ & & $\begin{array}{l}\text { 1017/18 Caliphate of } \\
\text { Córdoba (Islamic } \\
\text { Iberia along with a part } \\
\text { of North Africa) } \\
\text { collapses }\end{array}$ \\
\hline
\end{tabular}


TABLE 1.1 Chronological table of selected events of political and migration history (cont.)

$\begin{array}{llr}\text { Time } & \begin{array}{l}\text { Eastern- and } \\ \text { Southeastern Europe }\end{array} & \text { Central and Western Asia North and East Africa } \\ & \text { and (South) Arabia }\end{array}$

1027 Renewed peace

treaty between the

Byzantine Empire and

the Fatimid Caliph
1030/1042 Emer- 1036-1040 Conquest of
gence of the first
the Eastern Iranian
princedoms of
Province of Khorasan
immigrant mercenar- from the Ghaznavids by
ies from Normandy in Turkish groups under
Southern Italy
command of the Seljuk
dynasty

1031 End of Umayyad

1048-1053 Migration 1041/1042 Last raids of

of Pecheneg groups

Varangians from

1047-1138 Reign of

into the Byzantine

Scandinavia into the

Empire due to inner

Caspian Sea region

rule over Spain

conflicts and pressure

from the Oghuz and

Cumans

1055 Settlement of

1055 Capture of

1046 Emergence of the

Pecheneg groups in

Baghdad from the Buyids

the Shiite Sulaihid

Hungary

by the Seljuks

Dynasty in parts of

Yemen

Berber movement of

the Almoravids in

Western North Africa,

expansion into the

Iberian Peninsula and

across the Sahara; 1050

migrations ("invasion")

of Banu Hilal Bedouins

into North Africa

1064 Raids of the

1064 Seljuk conquest of

106o Almoravids found

Oghuz from the

the Armenian capital of

Marrakesh

Steppes into the

Ani (since 1045 under

Byzantine Balkans

Byzantine control)

1071 Loss of Bari as

1071 Defeat of the

last Byzantine outpost Byzantines against

1074 Badr al-Ǧamālī, a

in Southern Italy to

the Seljuks in the

general of Armenian

the Normans

Battle of Manzikert;

origin, becomes vizier

and de facto-ruler in 


\begin{tabular}{|c|c|c|c|}
\hline Time & $\begin{array}{l}\text { Eastern- and } \\
\text { Southeastern Europe }\end{array}$ & Central and Western Asia & $\begin{array}{l}\text { North and East Africa } \\
\text { and (South) Arabia }\end{array}$ \\
\hline & $\begin{array}{l}1081-1085 \text { Norman } \\
\text { attacks from Southern } \\
\text { Italy on the Byzantine } \\
\text { Balkans, which are } \\
\text { repelled with the help } \\
\text { of Venice, which } \\
\text { receives trade } \\
\text { privileges in the } \\
\text { Byzantine Empire; } \\
1085 \text { Toledo falls to } \\
\text { Reconquista Christian } \\
\text { forces }\end{array}$ & $\begin{array}{l}1072-1085 \text { Establish- } \\
\text { ment of an Armenian } \\
\text { princedom in Cilicia } \\
\text { after the collapse of } \\
\text { Byzantine power in the } \\
\text { region }\end{array}$ & $\begin{array}{l}\text { Fatimid Egypt (until his } \\
\text { death in 1094); } \\
\text { migrations of } \\
\text { Armenians to Egypt } \\
\text { 1o86 The Almoravids } \\
\text { under Yusuf ibn } \\
\text { Tashfin defeat an army } \\
\text { of the Castilian king } \\
\text { Alfonso vi in the battle } \\
\text { of Sagrajas (Zallaqa) }\end{array}$ \\
\hline & $\begin{array}{l}\text { 109o Saint Mark's } \\
\text { Cathedral built at } \\
\text { Venice; } 1091 \text { Comple- } \\
\text { tion of the Norman } \\
\text { conquest of Arab } \\
\text { Sicily }\end{array}$ & $\begin{array}{l}\text { Movement of the Nizari } \\
\text { assassins formed; } 1092 \\
\text { Death of the Seljuk } \\
\text { Sultan Malik Shah, } \\
\text { weakening of the central } \\
\text { power }\end{array}$ & $\begin{array}{l}\text { 1094-1121 al-Afḍal } \\
\text { Šāhanšāh, son of Badr } \\
\text { al-Ǧamālī, rules as } \\
\text { vizier in Fatimid Egypt }\end{array}$ \\
\hline 1100 & $\begin{array}{l}1091 \text { Byzantine } \\
\text { victory against the } \\
\text { Pechenegs in the } \\
\text { Battle of Levounion }\end{array}$ & $\begin{array}{l}\text { 1096-1099 First } \\
\text { Crusade, establishment } \\
\text { of four Frankish states in } \\
\text { the Levant, migrations } \\
\text { from Western Europe }\end{array}$ & $\begin{array}{l}1100 \text { The documents } \\
\text { in the Genizah of the } \\
\text { Ben Ezra-Synagogue in } \\
\text { Cairo hint at wide- } \\
\text { ranging trade networks } \\
\text { of the Jewish commu- } \\
\text { nity between North } \\
\text { Africa, the Red Sea and } \\
\text { India in the 11th and } \\
12 \text { th centuries }\end{array}$ \\
\hline & $\begin{array}{l}1111 \text { Trade privileges } \\
\text { for the city of Pisa in } \\
\text { the Byzantine Empire }\end{array}$ & $\begin{array}{l}\text { After } 1096 \text { Establish- } \\
\text { ment of the Seljuk } \\
\text { Sultanate of Rum in } \\
\text { central Anatolia }\end{array}$ & $\begin{array}{l}1107 \text { Formation of the } \\
\text { Almohad sect in North } \\
\text { Africa }\end{array}$ \\
\hline
\end{tabular}


TABLE 1.1 Chronological table of selected events of political and migration history (cont.)

\begin{tabular}{|c|c|c|c|}
\hline Time & $\begin{array}{l}\text { Eastern- and } \\
\text { Southeastern Europe }\end{array}$ & Central and Western Asia & $\begin{array}{l}\text { North and East Africa } \\
\text { and (South) Arabia }\end{array}$ \\
\hline & $\begin{array}{l}1122 \text { Decisive victory } \\
\text { of the Byzantine } \\
\text { Emperor John II } \\
\text { Komnenos against the } \\
\text { Pechenegs }\end{array}$ & $\begin{array}{l}1118 \text { Migration of } \\
\text { reportedly } 40,000 \\
\text { families of the Cumans } \\
\text { across the Caucasus into } \\
\text { Georgia }\end{array}$ & $\begin{array}{l}1118 \text { Crusader attack } \\
\text { on Egypt }\end{array}$ \\
\hline & $\begin{array}{l}1125 \text { Permanent } \\
\text { political fragmenta- } \\
\text { tion of the realm of } \\
\text { the Rus after the death } \\
\text { of Vladimir II } \\
\text { Monomakh }\end{array}$ & $\begin{array}{l}1125^{-1141} \text { Establish- } \\
\text { ment of the Empire of } \\
\text { the Kara Khitai in } \\
\text { Central Asia after their } \\
\text { emigration from } \\
\text { Manchuria due to their } \\
\text { defeat against the } \\
\text { Jurchen/Jin }\end{array}$ & $\begin{array}{l}\text { 1130-1269 Almohads } \\
\text { in North Africa and } \\
\text { (until 1212) in Spain }\end{array}$ \\
\hline & $\begin{array}{l}\text { 1147-1149 Norman } \\
\text { attacks from Southern } \\
\text { Italy on Byzantine } \\
\text { Greece }\end{array}$ & $\begin{array}{l}1144 \text { Conquest of the } \\
\text { Crusader princedom of } \\
\text { Edessa by Imad ad-Din } \\
\text { Zengi; } 1147-1149 \\
\text { Second Crusade }\end{array}$ & $\begin{array}{l}1147 \text { Collapse of the } \\
\text { Empire of the Al- } \\
\text { moravids, rise of the } \\
\text { Almohads }\end{array}$ \\
\hline & \multirow[t]{2}{*}{$\begin{array}{l}1154 \text { Death of Roger } \\
\text { II of Sicily, patron of } \\
\text { Islamic learning; } 1155 \\
\text { Trade privileges for } \\
\text { the city of Genoa in } \\
\text { the Byzantine Empire }\end{array}$} & $\begin{array}{l}1157 \text { Fragmentation of } \\
\text { the Seljuk Empire in Iran } \\
\text { after the death of Sultan } \\
\text { Ahmad Sanjar }\end{array}$ & $\begin{array}{l}\text { 1163-1184 The } \\
\text { Almohad Abu Ya'qub } \\
\text { Yusuf unifies most } \\
\text { parts of Spain under } \\
\text { his rule }\end{array}$ \\
\hline & & & $\begin{array}{l}\text { 1168/1169 Joint } \\
\text { Byzantine-Crusader } \\
\text { attack on Fatimid } \\
\text { Egypt }\end{array}$ \\
\hline & $\begin{array}{l}1171 \text { Temporal } \\
\text { eviction of the } \\
\text { Venetians from the } \\
\text { Byzantine Empire }\end{array}$ & $\begin{array}{l}1176 \text { Byzantine defeat } \\
\text { against the Seljuks of } \\
\text { Anatolia at } \\
\text { Myriokephalon }\end{array}$ & $\begin{array}{l}1171 \text { Replacement of } \\
\text { the Fatimid dynasty in } \\
\text { Egypt by the Ayyubids } \\
\text { (Sultan Saladin, of } \\
\text { Kurdish origin) }\end{array}$ \\
\hline
\end{tabular}




\begin{tabular}{|c|c|c|c|}
\hline Time & $\begin{array}{l}\text { Eastern- and } \\
\text { Southeastern Europe }\end{array}$ & Central and Western Asia & $\begin{array}{l}\text { North and East Africa } \\
\text { and (South) Arabia }\end{array}$ \\
\hline & $\begin{array}{l}1185 \text { Norman } \\
\text { conquest of Thessa- } \\
\text { lonike; rebellion in } \\
\text { Bulgaria against } \\
\text { Byzantine rule and } \\
\text { foundation of the } \\
\text { Second Bulgarian } \\
\text { Empire }\end{array}$ & $\begin{array}{l}1187 \text { Sultan Saladin } \\
\text { defeats the Crusaders at } \\
\text { Hattin and conquers } \\
\text { Jerusalem; } 1189-1192 \\
\text { Third Crusade }\end{array}$ & $\begin{array}{l}\text { 1173-1228 Reign of a } \\
\text { branch of the Ayyubid } \\
\text { Dynasty in Yemen }\end{array}$ \\
\hline & $\begin{array}{l}1195 \text { Byzantine } \\
\text { embassy to the } \\
\text { Scandinavian } \\
\text { kingdoms in order to } \\
\text { hire soldiers for the } \\
\text { Varangian Guard }\end{array}$ & $\begin{array}{l}1190 \text { Ghurids take Delhi; } \\
\text { Khwarazm Shahs expand } \\
\text { their power over western } \\
\text { Central Asia }\end{array}$ & $\begin{array}{l}\text { 1196-1549 Marinids } \\
\text { in Morocco }\end{array}$ \\
\hline 1200 & $\begin{array}{l}1204 \text { Fourth Crusade, } \\
\text { conquest of Constan- } \\
\text { tinople and establish- } \\
\text { ment of a "Latin } \\
\text { Empire" and further } \\
\text { Crusader states in } \\
\text { Greece }\end{array}$ & $\begin{array}{l}\text { 1205-1211 Seljuk } \\
\text { expansion in Anatolia } \\
\text { towards the Black Sea } \\
\text { and the Mediterranean }\end{array}$ & $\begin{array}{l}1200 \text { Rise of the } \\
\text { Kingdom of Mali in } \\
\text { Western Africa, first } \\
\text { pilgrimage of a prince } \\
\text { of the Mandinke to } \\
\text { Mecca }\end{array}$ \\
\hline & $\begin{array}{l}\text { 1204/1210 Venice } \\
\text { secures the possession } \\
\text { of the island of Crete } \\
\text { and further colonies in } \\
\text { the Aegean, migra- } \\
\text { tions from Venice and } \\
\text { other parts of Italy }\end{array}$ & $\begin{array}{l}1206 \text { Proclamation of } \\
\text { Temujin as Genghis Khan } \\
\text { of the Mongols; the } \\
\text { following Mongol } \\
\text { conquests cause } \\
\text { wide-ranging movements } \\
\text { of troops, refugees, } \\
\text { deportees and migrants } \\
\text { across Eurasia }\end{array}$ & $\begin{array}{l}\text { 1218-1221 Fifth } \\
\text { Crusade, attack on } \\
\text { Egypt and temporal } \\
\text { occupation of the city } \\
\text { of Damiette }\end{array}$ \\
\hline & $\begin{array}{l}1223 \text { Victory of a } \\
\text { Mongol army over } \\
\text { Russian and Cuman } \\
\text { troops in the Battle of } \\
\text { Kalka }\end{array}$ & $\begin{array}{l}\text { 1221-1231 Devastating } \\
\text { campaigns of the Sultan } \\
\text { Jalal al-Din of Khwārazm } \\
\text { in Western Iran, Caucasia } \\
\text { and Mesopotamia after } \\
\text { his defeat against the } \\
\text { Mongols }\end{array}$ & $\begin{array}{l}1228-1454 \text { Reign of } \\
\text { the Rasulid Dynasty in } \\
\text { Yemen }\end{array}$ \\
\hline
\end{tabular}


TABLE 1.1 Chronological table of selected events of political and migration history (cont.)

$\begin{array}{llr}\text { Time } & \text { Eastern- and } & \text { Central and Western Asia North and East Africa } \\ \text { Southeastern Europe } & \text { and (South) Arabia }\end{array}$

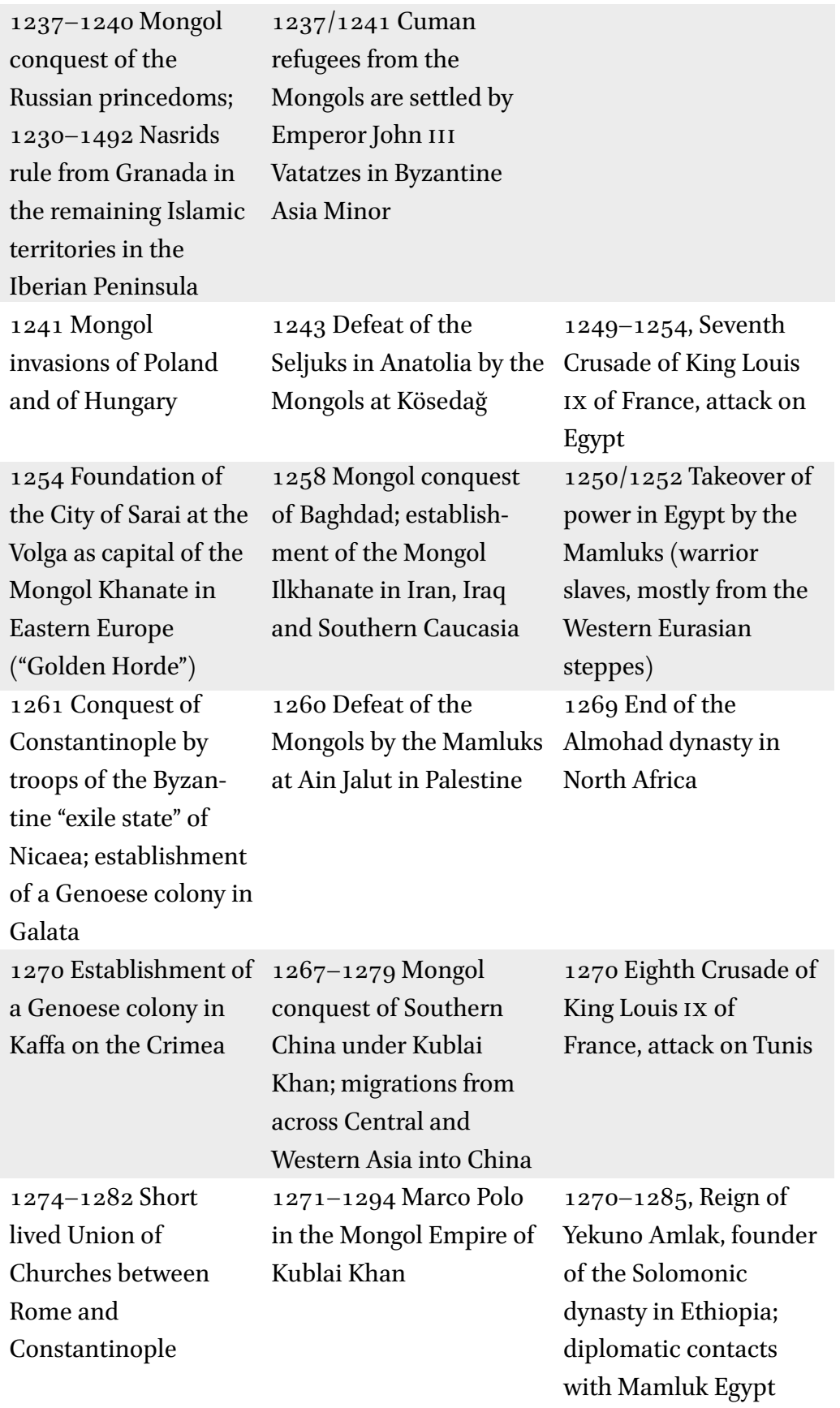




\begin{tabular}{|c|c|c|c|}
\hline Time & $\begin{array}{l}\text { Eastern- and } \\
\text { Southeastern Europe }\end{array}$ & d Western Asia & $\begin{array}{l}\text { North and East Africa } \\
\text { and (South) Arabia }\end{array}$ \\
\hline & $\begin{array}{l}\text { 1294-1302 War } \\
\text { between the Byzan- } \\
\text { tine Empire and } \\
\text { Venice }\end{array}$ & $\begin{array}{l}1291 \text { Fall of Acre as last } \\
\text { outpost of the Crusaders } \\
\text { at the mainland Levan- } \\
\text { tine coast to the Mam- } \\
\text { luks; } 1296 \text { Defections of } \\
\text { thousands of Oirat } \\
\text { warriors and their } \\
\text { families (originally } \\
\text { coming from Southern } \\
\text { Siberia) from the Ilkhan } \\
\text { Empire to the Mamluk } \\
\text { Sultanate }\end{array}$ & $\begin{array}{l}1285 \text { Emergence of the } \\
\text { Sultanate of Ifat in } \\
\text { Ethiopia }\end{array}$ \\
\hline \multirow[t]{4}{*}{1300} & $\begin{array}{l}1302 \text { Migration of } \\
\text { followers of the } \\
\text { defeated Khan Nogai } \\
\text { after a civil war in the } \\
\text { Golden Horde to } \\
\text { Byzantium }\end{array}$ & $\begin{array}{l}1302 \text { First defeat of the } \\
\text { Byzantines against the } \\
\text { Ottomans at Bapheus; } \\
\text { refugees from the } \\
\text { conquered areas in } \\
\text { Western Asia Minor } \\
\text { come to Constantinople }\end{array}$ & $\begin{array}{l}1306 \text { Embassy of King } \\
\text { Wedem Arad of } \\
\text { Ethiopia to the Papacy }\end{array}$ \\
\hline & $\begin{array}{l}1311 \text { First relocation } \\
\text { of the see of the } \\
\text { Metropolitan of } \\
\text { Russia from Kiev to } \\
\text { Moscow }\end{array}$ & $\begin{array}{l}\text { 1307/1318 Establish- } \\
\text { ment of Catholic } \\
\text { bishoprics in the Mongol } \\
\text { capitals in China } \\
\text { (Beijing) and Persia } \\
\text { (Sultaniyya) }\end{array}$ & $\begin{array}{l}\text { 1310-1333 Apex of } \\
\text { the Sultanate of Kilwa } \\
\text { Kisiwani in Tanzania in } \\
\text { the reign of al-Hasan } \\
\text { ibn Sulaiman, who is } \\
\text { also visited by the } \\
\text { traveller Ibn Battuta }\end{array}$ \\
\hline & $\begin{array}{l}1321-1328 \text { Civil war } \\
\text { in the Byzantine } \\
\text { Empire }\end{array}$ & $\begin{array}{l}1326 \text { Ottoman conquest } \\
\text { of the Byzantine city of } \\
\text { Bursa (Prusa) in North- } \\
\text { west Asia Minor }\end{array}$ & $\begin{array}{l}1312 \text { Mamluk invasion } \\
\text { of the Nubian Kingdom } \\
\text { of Makuria, a Muslim } \\
\text { member of the royal } \\
\text { dynasty is put on the } \\
\text { throne }\end{array}$ \\
\hline & $\begin{array}{l}1327 \text { Acknowledge- } \\
\text { ment of Prince Ivan I } \\
\text { of Moscow as Grand } \\
\text { Prince of Russia by the } \\
\text { Golden Horde }\end{array}$ & $\begin{array}{l}1331 \text { Ottoman conquest } \\
\text { of the Byzantine city of } \\
\text { Nikaia (Iznik) in } \\
\text { Northwest Asia Minor }\end{array}$ & $\begin{array}{l}1324 \text { Pilgrimage of } \\
\text { King Mansa Musa I of } \\
\text { Mali from West Africa } \\
\text { to Mecca }\end{array}$ \\
\hline
\end{tabular}


TABLE 1.1 Chronological table of selected events of political and migration history (cont.)

$\begin{array}{llr}\text { Time } & \begin{array}{l}\text { Eastern- and } \\ \text { Southeastern Europe }\end{array} & \text { Central and Western Asia North and East Africa } \\ & \text { and (South) Arabia }\end{array}$

1340 Expansion of the 1335 Fragmentation of

Kingdom of Poland the Mongol Ilkhanate

and of the Grand after the death of Abù

Duke of Lithuania into $\mathrm{Sa}^{\mathrm{c} i \mathrm{i}}$

Western Russian

regions

\begin{tabular}{|c|c|c|c|}
\hline & $\begin{array}{l}135^{2} \text { Ottoman } \\
\text { capture of the fortress } \\
\text { of Tzympe, start of } \\
\text { their expansion into } \\
\text { the Balkans }\end{array}$ & $\begin{array}{l}1346 \text { Outbreak of the } \\
\text { Plague epidemic of the } \\
\text { "Black Death" across } \\
\text { Western Afro-Eurasia }\end{array}$ & $\begin{array}{l}1346 \text { Outbreak of the } \\
\text { Plague epidemic of the } \\
\text { "Black Death" across } \\
\text { Western Afro-Eurasia }\end{array}$ \\
\hline & $\begin{array}{l}1362 \text { Ottoman } \\
\text { conquest of the } \\
\text { Byzantine city of } \\
\text { Adrianople (Edirne) }\end{array}$ & $\begin{array}{l}1368 \text { Overthrow of the } \\
\text { Mongol Yuan Dynasty in } \\
\text { China by the Ming }\end{array}$ & $\begin{array}{l}1365 \text { Attack of a } \\
\text { Crusader army from } \\
\text { Cyprus on Alexandria } \\
\text { in Egypt }\end{array}$ \\
\hline & $\begin{array}{l}1371 \text { Ottoman victory } \\
\text { over an alliance of } \\
\text { Serbian princes in the } \\
\text { Battle at the river } \\
\text { Maritza }\end{array}$ & $\begin{array}{l}\text { 1370-1405 Establish- } \\
\text { ment of a new Mongol } \\
\text { Empire in western } \\
\text { Central Asia and Iran by } \\
\text { Timur Leng }\end{array}$ & \\
\hline & $\begin{array}{l}1389 \text { Ottoman victory } \\
\text { over an alliance of } \\
\text { Christian princes in } \\
\text { the Battle of Kosovo } \\
\text { Polje }\end{array}$ & $\begin{array}{l}\text { 1381-1392 Ottoman } \\
\text { conquest of most of the } \\
\text { competing Turkish } \\
\text { Emirates in Western Asia } \\
\text { Minor }\end{array}$ & $\begin{array}{l}1382 \text { Establishment of } \\
\text { the Burji dynasty in the } \\
\text { Mamluk Sultanate }\end{array}$ \\
\hline & $\begin{array}{l}\text { 1395-1402 First } \\
\text { Ottoman siege of } \\
\text { Constantinople }\end{array}$ & $\begin{array}{l}\text { 1390-1399 Devastating } \\
\text { campaigns of Timur Leng } \\
\text { into India and against } \\
\text { the Golden Horde }\end{array}$ & \\
\hline 1400 & $\begin{array}{l}\text { 1402-1413 Civil war } \\
\text { in the Ottoman } \\
\text { Empire }\end{array}$ & $\begin{array}{l}1402 \text { Ottoman defeat } \\
\text { against Timur Leng in } \\
\text { the Battle of Ankara }\end{array}$ & \\
\hline & $\begin{array}{l}1410 \text { Death of the } \\
\text { famous Byzantine } \\
\text { Icon painter Theo- } \\
\text { phanes in Russia }\end{array}$ & & $\begin{array}{l}1415 \text { Emergence of the } \\
\text { Adal Sultanate at the } \\
\text { Horn of Africa }\end{array}$ \\
\hline
\end{tabular}




\begin{tabular}{|c|c|c|c|}
\hline Time & $\begin{array}{l}\text { Eastern- and } \\
\text { Southeastern Europe }\end{array}$ & Central and Western Asia & $\begin{array}{l}\text { North and East Africa } \\
\text { and (South) Arabia }\end{array}$ \\
\hline & $\begin{array}{l}1422 \text { Second Ottoman } \\
\text { siege of } \\
\text { Constantinople }\end{array}$ & & $\begin{array}{l}1415 \text { Conquest of } \\
\text { Ceuta in North Africa } \\
\text { by Portugal }\end{array}$ \\
\hline & $\begin{array}{l}\text { 1423-1432 First war } \\
\text { between the Otto- } \\
\text { mans and Venice }\end{array}$ & & $\begin{array}{l}1434 \text { Portuguese } \\
\text { seafarers reach Cape } \\
\text { Bojador in West Africa }\end{array}$ \\
\hline & $\begin{array}{l}1444 \text { Defeat of King } \\
\text { Vladislav III of } \\
\text { Hungary and Poland } \\
\text { against the Ottomans } \\
\text { in the Battle of Varna }\end{array}$ & $\begin{array}{l}1447 \text { Ultimate collapse } \\
\text { of Timurid rule in Iran, } \\
\text { rise of the Turkish } \\
\text { federation of the Qara } \\
\text { Qoyunlu }\end{array}$ & \\
\hline & $\begin{array}{l}1453 \text { The Ottoman } \\
\text { Sultan Mehmed II } \\
\text { conquers } \\
\text { Constantinople }\end{array}$ & & $\begin{array}{l}1456 \text { Portuguese } \\
\text { seafarers reach Cap } \\
\text { Verde islands }\end{array}$ \\
\hline & $\begin{array}{l}\text { 146o Conquest of the } \\
\text { Peloponnese by the } \\
\text { Ottomans }\end{array}$ & $\begin{array}{l}1467 \text { Defeat of the Qara } \\
\text { Qoyunlu by the Aq } \\
\text { Qoyunlu under Uzun } \\
\text { Hasan }\end{array}$ & $\begin{array}{l}1465^{-1492} \text { Rise of the } \\
\text { Empire of Songhay in } \\
\text { Western Africa under } \\
\text { the rule of Sonni Ali }\end{array}$ \\
\hline
\end{tabular}

\begin{tabular}{|c|c|c|c|}
\hline & $\begin{array}{l}1475 \text { Conquest of the } \\
\text { last Genoese colonies } \\
\text { on the Crimea by an } \\
\text { alliance of the } \\
\text { Khanate of the Crimea } \\
\text { and the Ottomans }\end{array}$ & & \\
\hline & & & $\begin{array}{l}1482 \text { The Portuguese } \\
\text { reach the mouth of the } \\
\text { river Congo }\end{array}$ \\
\hline & $\begin{array}{l}1492 \text { Expulsion of } \\
\text { Jews from Spain, many } \\
\text { find refuge in the } \\
\text { Ottoman Empire }\end{array}$ & $\begin{array}{l}\text { Formation of several } \\
\text { Muslim petty states in } \\
\text { India; } 1498 \text { Vasco da } \\
\text { Gama lands in Calicut }\end{array}$ & $\begin{array}{l}\text { 1487/1488 The } \\
\text { Portuguese Bartolomeu } \\
\text { Dias reaches the Cape } \\
\text { of Good Hope }\end{array}$ \\
\hline 1500 & & $\begin{array}{l}\text { 1501-1507 Overthrow of } \\
\text { the Aq Qoyunlu by the } \\
\text { Shiite Safavid dynasty in } \\
\text { Iran }\end{array}$ & $\begin{array}{l}1500 \text { Collapse of the } \\
\text { Christian Nubian } \\
\text { Kingdom }\end{array}$ \\
\hline
\end{tabular}


TABLE 1.1 Chronological table of selected events of political and migration history (cont.)

\begin{tabular}{|c|c|c|c|}
\hline Time & $\begin{array}{l}\text { Eastern- and } \\
\text { Southeastern Europe }\end{array}$ & Central and Western Asia & $\begin{array}{l}\text { North and East Africa } \\
\text { and (South) Arabia }\end{array}$ \\
\hline & & $\begin{array}{l}\text { 1509-1511 Revolts } \\
\text { under the leadership of } \\
\text { Shiite clergymen and } \\
\text { dervishes in Ottoman } \\
\text { Anatolia }\end{array}$ & $\begin{array}{l}15^{16 / 1517} \text { Ottoman } \\
\text { conquest of the } \\
\text { Mamluk Sultanate in } \\
\text { Syrian and Egypt }\end{array}$ \\
\hline & $\begin{array}{l}15^{26} \text { Ottoman defeat } \\
\text { of the army of the } \\
\text { Kingdom of Hungary in } \\
\text { the Battle of Mohács }\end{array}$ & & \\
\hline
\end{tabular}

\section{Acknowledgement}

The (open access) publication of this volume was financed within the framework of the project "Moving Byzantium: Mobility, Microstructures and Personal Agency", directed by Prof. Claudia Rapp (Vienna) and funded by the FWF Austrian Science Fund (Project Z 288 Wittgenstein-Preis). For more information on this project, see https://rapp.univie.ac.at/.

\section{Bibliography}

Aberth, J., Contesting the Middle Ages. Debates that are Changing our Narrative of Medieval History, London/New York 2019.

Abu-Lughod, J.L., Before European Hegemony. The World System A.D. 1250-1350, New York/Oxford 1989 .

Alram, M., Das Antlitz des Fremden. Die Münzprägung der Hunnen und Westtürken in Zentralasien und Indien, Vienna 2016.

Allsen, Th. T., Culture and Conquest in Mongol Eurasia, Cambridge 2001.

Allsen, Th. T., "Population Movements in Mongol Eurasia", in: R. Amitai/M. Biran (eds.), Nomads as Agents of Cultural Change. The Mongols and Their Eurasian Predecessors, Honolulu 2015, pp. 119-154.

Amitai-Preiss, R., Mongols and Mamluks. The Mamluk-İlkhānid Wars, 1260-1281, Cambridge 1995 . 
Amorim, C.E.G., et al., "Understanding 6th-century barbarian social organization and migration through paleogenomics", Nature Communications 9, Article number: 3547 (2018): https://www.nature.com/articles/s41467-018-06024-4.

Avanzini, A., By Land and by Sea. A History of South Arabia before Islam recounted from Inscriptions, Rome 2016.

Baker, B./Takeyuki, T. (eds.), Migration and Disruptions. Toward a Unifying Theory of Ancient and Contemporary Migrations, Gainesville et al. 2015.

Balard, M./Ducellier, A. (eds.), Migrations et diasporas méditerranéennes (Xe-XVIe siècles), Paris 2002.

Barkey, K., Empire of Difference. The Ottomans in Comparative Perspective, Cambridge 2008.

Bartlett, R., The Making of Europe: Conquest, Colonization and Cultural Change 9501350, London 1993.

Baumer, Ch., The History of Central Asia: The Age of the Silk Road, London/New York 2014.

Beaujard, Ph., Les mondes de l'ocean indien, 2 Vols., Paris 2012.

Bechhaus-Gerst, M., “Afrika”, in: M. Borgolte (ed.), Migrationen im Mittelalter: Ein Handbuch, Berlin 2017, pp. 107-117.

Beihammer, A.D., Byzantium and the Emergence of Muslim-Turkish Anatolia, ca. 10401130, Abingdon 2017.

Ben-Sasson, H.H., Geschichte des jüdischen Volkes. Von den Anfängen bis zur Gegenwart, Munich 1994.

Berger, L., "Muslimische Welt", in: M. Borgolte (ed.), Migrationen im Mittelalter: Ein Handbuch, Berlin 2017, pp. 129-140.

Bösl, E., Doing Ancient DNA: Zur Wissenschaftsgeschichte der aDNA-Forschung, Bielefeld 2017.

Borgolte, M. (ed.), Migrationen im Mittelalter: Ein Handbuch, Berlin 2017.

Borgolte, M., "Einführung”, in: M. Borgolte (ed.), Migrationen im Mittelalter: Ein Handbuch, Berlin 2017, pp. 11-20.

Borgolte, M., "Migrationen im Mittelalter. Ein Überblick”, in: M. Borgolte (ed.), Migrationen im Mittelalter: Ein Handbuch, Berlin 2017, pp. 21-33.

Bossong, G., Die Sepharden. Geschichte und Kultur der spanischen Juden, Munich 2008.

Bowlus, C.R., The Battle of Lechfeld and its Aftermath, August 955. The End of the Age of Migrations in the Latin West, Aldershot 2006.

Büntgen, Ulf, et al., "Cooling and societal change during the Late Antique Little Ice Age from 536 to around 66o AD", Nature Geoscience 9 (2016), 231-236.

Burmeister, St., "Archaeology and Migration: Approaches to an Archaeological Proof of Migration", Current Anthropology 41/4, August/October 2000, pp. 539-567.

Burns, E.J., Sea of Silk. A Textile Geography of Women's Work in Medieval French Literature, Philadelphia 2009. 
Campbell, B.M.S., The Great Transition: Climate, Disease and Society in the Late Medieval World, Cambridge 2016.

Chaffee, J.W., The Muslim merchants of Premodern China. The History of a Maritime Asian Trade Diaspora, 750-1400, Cambridge 2018.

Christie, N., The Lombards. The Ancient Longobards, Oxford 1995.

Ciocilltan, V., The Mongols and the Black Sea Trade in the Thirteenth and Fourteenth Centuries, Leiden/Boston 2012.

Cohen, R., Global Diasporas: An Introduction, London/New York 2008.

Cunliffe, B., By Steppe, Desert, and Ocean. The Birth of Eurasia, Oxford 2015.

Cunliffe, B., On the Ocean. The Mediterranean and the Atlantic from Prehistory of $A D$ 1500, Oxford 2017.

Curta, F., The Making of the Slavs: History and Archaeology of the Lower Danube Region, c.500-700, Cambridge 2001.

Curta, F., Southeastern Europe in the Middle Ages 500-1250, Cambridge 2006.

Curtin, Ph. D., Cross-cultural Trade in World history, Cambridge 1984.

de Barros Damgaard, P., et al., "137 ancient human genomes from across the Eurasian steppes”, Nature 557 (17 May 2018), 369-374.

Demandt, A., Der Fall Roms. Die Auflösung des römischen Reiches im Urteil der Nachwelt, Munich 2014.

di Branco, M./Wolf, K., "Berber und Araber im Maghreb und Europa", in: M. Borgolte (ed.), Migrationen im Mittelalter: Ein Handbuch, Berlin 2017, pp. 149-160.

Ditten, H., Ethnische Verschiebungen zwischen der Balkanhalbinsel und Kleinasien vom Ende des 6. bis zur zweiten Hälfte des 9. Jahrhunderts, Berliner Byzantinische Arbeiten 59, Berlin 1993.

Dold-Ghadar, G., Pers-Andalus: iranische Kulturdenkmäler in "al-Andalus al-aqșā": Bewertung der Forschungsergebnisse für das 8.-12. Jahrhundert, Berlin 2016.

Eastmond, A., Tamta's World. The Life and Encounters of a Medieval Noblewoman from the Middle East to Mongolia, Cambridge 2017.

Eggert, M.K.H., "The Bantu Problem and African Archaeology”, in: A.B. Stahl (ed.), African Archaeology: A Critical Introduction, Malden/Oxford 2004, pp. 301-326.

Ellenblum, R., Frankish Rural Settlement in the Latin Kingdom ofJerusalem, Cambridge 1998.

Ellenblum, R., The Collapse of the Eastern Mediterranean: Climate Change and the Decline of the East, 950-1072, Cambridge, 2012.

Epstein, St. A., Purity Lost: Transgressing Boundaries in the Eastern Mediterranean, 1000-1400, Baltimore 2007.

Faroqhi, S., Travel and Artisans in the Ottoman Empire: Employment and Mobility in the Early Modern Era, London 2014.

Fauvelle, F.-X., Das Goldene Rhinozeros. Afrika im Mittelalter, Munich 2017. 
Fauvelle, F.-X. (ed.), L'Afrique ancienne: De l'Acacus au Zimbabwe. 20 ooo avant notre èreXVIIe siècle, Paris 2018.

Ferrier, C., L'Inde des Gupta (IVe-VI siécle), Paris 2015.

Feuchter, J., "Über die Herausforderung der Geschichtswissenschaft durch die Genetik: Zwölf Thesen zur Genetic History", 2016 online: https://mittelalter.hypotheses .org/7629.

Fleet, K., European and Islamic Trade in the early Ottoman State. The Merchants of Genoa and Turkey, Cambridge 1999.

Fleet, K., "The Turkish economy, 1071-1453", in: idem (ed.), The Cambridge History of Turkey, Vol. I: Byzantium to Turkey 1071-1453, Cambridge 2009, pp. 227-265.

Flood, F.B., Objects of Translation. Material Culture and Medieval "Hindu-Muslim" Encounter, Princeton/Oxford 2009.

Fraser, A., The Gypsies, Malden/Oxford 1995.

Gandila, A., Cultural Encounters on Byzantium's Northern Frontier, c. AD 500-70o. Coins, Artefacts and History, Cambridge 2018.

Gil, M., "The Radhanite Merchants and the Land of Radhan", Journal of the Economic and Social History of the Orient 17, 1974, 299-328.

Golden, P.B./Ben-Shammai, H./Róna-Tas, A. (eds.), The World of the Khazars. New Perspectives, Leiden/Boston 2007.

Gomez, M.A., African Dominion. A new History of Empire in Early and Medieval West Africa, Princeton/Oxford 2018.

Gordon, M.S., The Breaking of a Thousand Swords. A History of the Turkish Military of Samarra (A.H. 200-275/815-889 C.E.), Albany 2001.

Hahn, S., Historische Migrationsforschung, Frankfurt/New York 2012.

Halperin, C.J., "The Kipchak connection: the lkhans, the Mamluks and Ayn Jalut", Bulletin of the School of Oriental and African Studies 63, 2000, 229-245.

Halsall, G., Barbarian Migrations and the Roman West 376-568, Cambridge 2007.

Hardt, M., "Slawen", in: M. Borgolte (ed.), Migrationen im Mittelalter: Ein Handbuch, Berlin 2017, pp. 171-180.

Härke, H., "Archaeologists and Migrations: A Problem of Attitude?", Current Anthropology 39/1, February 1998, pp. 19-46.

Harzig, C./Hoerder, D., with D. Gabaccia, What is Migration History?, Malden, MA 2009 .

Hatke, G., Aksum and Nubia. Warfare, Commerce and Political Fictions in Ancient Northeast Africa, New York 2013.

Hawkes, J.D./Wynne-Jones, St., "India in Africa: Trade goods and connections of the late first millennium", Afriques o6 (2015), online: https://afriques.revues.org/1752.

Heers, J., Les négriers en terres d'islam, VII - -XVIe siècle, Paris 2007.

Hillenbrand, C., The Crusades: Islamic Perspectives, corrected reprint, Edinburgh 2006. 
Hoerder, D., Cultures in Contact. World Migrations in the Second Millennium, Durham/ London 2002.

Horton, M./Middleton, J., The Swahili, Oxford/Malden 2000.

Imber, C., The Ottoman Empire, 1300-1650: The Structure of Power, Basingstoke 2009.

Jackson, P, The Mongols and the Islamic World: From Conquest to Conversion, Yale 2017.

Jackson, P, The Mongols and the West, 1221-1410, 2nd ed. London 2018.

Jacoby, D., "Silk Economics and Cross-Cultural Artistic Interaction: Byzantium, the Muslim World, and the Christian West", Dumbarton Oaks Papers $5^{8}$ (2004), 197-240.

Kafadar, C., Between Two Worlds. The Construction of the Ottoman State, Berkeley/Los Angeles/London 1996.

Kahane, H./Kahane, R./Tietze, A., The Lingua Franca of the Levant. Turkish Nautical Terms of Italian and Greek Origin, Urbana, Illinois 1958.

Kaldellis, A., Streams of Gold, Rivers of Blood: The Rise and Fall of Byzantium, 955 A.D. to the First Crusade, Oxford 2017.

Kaldellis, A., Romanland. Ethnicity and Empire in Byzantium, Cambridge, Mass./London 2019 .

Kardaras, G., Byzantium and the Avars, 6th-gth Century AD: Political, Diplomatic and Cultural Relations, Leiden/Boston 2018.

Kim, H.J., The Huns, Abingdon 2016.

Korobeinikov, D., "A broken mirror: the Kıpçak world in the thirteenth century", in: F. Curta (ed.), The Other Europe in the Middle Ages. Avars, Bulgars, Khazars, and Cumans, East Central and Eastern Europe in the Middle Ages, 450-1450, Leiden/Boston 2008, pp. 379-410.

Korobeinikov, D., Byzantium and the Turks in the Thirteenth Century, Oxford 2014.

Krämer, F./Schmidt, K./Singer, J. (eds.), Historicing the "Beyond". The Mongolian Invasion as a new Dimension of Violence, Heidelberg 2011.

Krause, J., with Trappe, Th., Die Reise unserer Gene. Eine Geschichte über uns und unsere Vorfahren, Berlin 2019.

Kulke, H., Das europäische Mittelalter - ein eurasisches Mittelalter?, Berlin 2016.

Kulke, H./Rothermund, D., Geschichte Indiens. Von der Induskultur bis heute, Munich 2010.

Le Goff, J., Faut-il vraiment découper l'histoire en tranches?, Paris 2016.

Lewis, M.E., China between Empires. The Northern and Southern Dynasties, Cambridge, Mass./London 2009.

Lilie, R.-J., Handel und Politik zwischen dem byzantinischen Reich und den italienischen Kommunen Venedig, Pisa und Genua in der Epoche der Komnenen und der Angeloi (1081-1204), Amsterdam 1984.

Loiseau, J., Les Mamelouks XIII -XVIe siècle: Une expérience du pouvoir dans l'islam medieval, Paris 2014. 
Lombard, M., Blütezeit des Islam. Eine Wirtschafts- und Kulturgeschichte 8.-11.Jahrhundert, Frankfurt am Main 1992.

Luft, St., Die Flüchtlingskrise. Ursachen, Konflikte, Folgen, Munich 2016.

Mack, R.E., Bazaar to Piazza. Islamic Trade and Italian Art, 1300-16oo, Berkeley/Los Angeles/London 2002.

Makris, G., Studien zur spätbyzantinischen Schiffahrt, Genoa 1988.

Malamut, É./Ouerfelli, M. (eds.), Les échanges en Méditerranée médiévale, Aix-enProvence 2012.

Marboe, R.A., Von Burgos nach Cuzco. Das Werden Spaniens 530-1530, Essen 2006.

McCormick, M., "New Light on the Dark Ages: How the Slave Trade Fueled the Carolingian Economy", Past and Present 177 (2002), 17-54.

McCormick, M., et al., "Climate Change during and after the Roman Empire: Reconstructing the Past from Scientific and Historical Evidence", Journal of Interdisciplinary History 43 (2) (2012), 169-220.

McLeman, R.A., Climate and Human Migration: Past Experiences, Future Challenges, Cambridge 2013 .

Meško, M., "Pecheneg groups in the Balkans (ca. 1053-1091) according to the Byzantine sources", in: F. Curta/B.-P. Maleon (eds.), The Steppe Lands and the World beyond them. Studies in honor of Victor Spinei on his 7oth birthday, Iași 2013, pp. 179-205.

Middleton, J., World of Swahili: An African Mercantile Civilization, New Haven 1994.

Mitsiou, E./Preiser-Kapeller, J., "Moving Hands: Types and Scales of Labour Mobility in the Late Medieval Eastern Mediterranean (1200-1500 CE)", in: C.G. de Vito/A. Gerritsen (eds.), Micro-Spatial Histories of Global Labour, London 2017, pp. 29-67.

Nagel, T., Timur der Eroberer und die islamische Welt des späten Mittelalters, Munich 1993.

Orthmann, E., Stamm und Macht. Die arabischen Stämme im 2. und 3. Jahrhundert der Hidschra, Wiesbaden 2002.

Pálóczi-Horváth, A., Pechenegs, Cumans, Iasians. Steppe peoples in medieval Hungary, Budapest 1989.

Peacock, A.C.S, The Great Seljuk Empire, Edinburgh 2015.

Plassmann, A., Origo gentis: Identitäts- und Legitimitätsstiftung in früh- und hochmittelalterlichen Herkunftserzählungen, Berlin 2006.

Pohl, W. (ed.), The Genetic Challenge to Medieval History and Archaeology, Medieval Worlds 4 (2016), online: https://www.medievalworlds.net/8084-5inhalt?frames =yes.

Pohl, W., Die Völkerwanderung: Eroberung und Integration, 3rd ed. Stuttgart 2020.

Pohl, W., The Avars: A Steppe Empire in Central Europe, 567-822, Ithaca/London 2018.

Popovic, A., The Revolt of African Slaves in Iraq in the 3rd/gth Century, Princeton, N.J. 1999.

Power, T., The Red Sea from Byzantium to the Caliphate: AD 500-1000, Cairo 2012. 
Prange, S.R., Monsoon Islam. Trade and Faith on the Medieval Malabar Coast, Cambridge 2018.

Preiser-Kapeller, J., "Networks of border zones - multiplex relations of power, religion and economy in South-eastern Europe, 1250-1453 CE", in: Proceedings of the 39th Annual Conference of Computer Applications and Quantitative Methods in Archaeology, "Revive the Past" (CAA) in Beijing, China, Amsterdam 2012, 381-393.

Preiser-Kapeller, J., "A Collapse of the Eastern Mediterranean? New results and theories on the interplay between climate and societies in Byzantium and the Near East, ca. 1000-1200 AD", Jahrbuch der Österreichischen Byzantinistik 65, 2015, 195-242.

Preiser-Kapeller, J., "Byzantinische Geschichte, 1025-1204", in: F. Daim (ed.), Byzanz. Historisch-kulturwissenschaftliches Handbuch, Neuer Pauly, Supplement 11, Stuttgart 2016, pp. 130-195.

Preiser-Kapeller, J., "Complex processes of migration: the south Caucasus in the early Islamic Empire (7th-10th century AD)", in: H. Mehler/F. Daim/J. Krause/R. Risch (eds.), Migration und Integration von der Urgeschichte bis zum Mittelalter, Halle 2017, pp. 295-313.

Preiser-Kapeller, J., Jenseits von Rom und Karl dem Großen. Aspekte der globalen Verflechtung in der langen Spätantike, 300-80o n. Chr., Vienna 2018.

Preiser-Kapeller, J./Mitsiou, Ek., "Mercantile and religious mobility between Byzantines, Latins and Muslims, 1200-1500: on the theory and practice of social networks", Medieval Worlds, Issue 1/2019, online: https://www.medievalworlds .net/oxc1aa5576\%20oxoo3abd7e.pdf.

Raffensperger, Ch., Reimagining Europe: Kievan Rus' in the Medieval World, 988-1146, Harvard 2012

Ravid, B., "Venice and its Minorities", in: E. Dursteler (ed.), A Companion to Venetian History, 1400-1797, Leiden/Boston 2013, pp. 449-485.

Reichert, F.E., Begegnungen mit China: Die Entdeckung Ostasiens im Mittelalter, Stuttgart 1992.

Rezakhani, Kh., ReOrienting the Sasanians. East Iran in Late Antiquity, Edinburgh 2017. Róna-Tas, A., Hungarians and Europe in the Early Middle Ages: An Introduction to Early Hungarian History, Budapest 1999.

Rotman, Y., Byzantine Slavery and the Mediterranean World, Cambridge, Mass./London 2009.

Scheel, R., Skandinavien und Byzanz: Bedingungen und Konsequenzen mittelalterlicher Kulturbeziehungen, Bonn 2015.

Schiel, J., "Sklaven", in: M. Borgolte (ed.), Migrationen im Mittelalter: Ein Handbuch, Berlin 2017, pp. 251-266.

Schmiedchen, A., “Indien", in: M. Borgolte (ed.), Migrationen im Mittelalter: Ein Handbuch, Berlin 2017, pp. 67-80.

Schuppert, G.F., Verflochtene Staatlichkeit. Globalisierung als Governance-Geschichte, Frankfurt/New York 2014. 
Schwenken, H., Globale Migration zur Einführung, Hamburg 2018.

Sénac, Ph., Charlemagne et Mahomet en Espagne (VIIIe-IXe siècles), Paris 2015.

Shukurov, R., The Byzantine Turks, 1204-1461, Leiden/Boston 2016.

Skinner, P., Medieval Amalfi and Its Diaspora, 800-1250, Oxford 2013.

Spinei, V. The Romanians and the Turkic Nomads North of the Danube Delta from the Tenth to the Mid-Thirteenth Century, Leiden/Boston 2009.

Stephenson, P., Byzantium's Balkan Frontier. A Political Study of the Northern Balkans, 900-1204, Cambridge 2000.

Stickler, Th., Die Hunnen, Munich 2007.

Tannous, J., The Making of the Medieval Middle East: Religion, Society, and Simple Believers, Princeton 2018.

Theotokis, G., The Norman Campaigns in the Balkans, 1081-1108, Woodbridge 2014.

Tilly, Ch., "Transplanted Networks", in: V. Yans-McLaughlin (ed.), Immigration Reconsidered. History, Sociology and Politics, New York/Oxford 1990, pp. 79-95.

Toch, M., The economic history of European Jews: Late antiquity and early middle ages, Leiden/Boston 2013

Vásáry, I., Cumans and Tatars. Oriental Military in the Pre-Ottoman Balkans, 1185-1365, Cambridge 2005.

von Padberg, L., Christianisierung im Mittelalter, Stuttgart 2006.

Ward-Perkins, B., The Fall of Rome and the End of Civilization, Oxford 2006.

Wardwell, A.E., "Panni Tartarici: Eastern Islamic Silks Woven with Gold and Silver (13th and 14th Centuries)", Islamic Art 3 (1988/89), 95-173.

Werner, E., Die Geburt einer Großmacht. Die Osmanen (1300-1481). Ein Beitrag zur Genesis des türkischen Feudalismus, Weimar 1985.

Wickham, Ch., The Inheritance of Rome. A History of Europe from 400 to 10oo, London 2009.

Yıldız, S.N., "Reconceptualizing the Seljuk-Cilician Frontier: Armenians, Latins, and Turks in Conflict and Alliance during the Early Thirteenth Century", in: F. Curta (ed.), Borders, Barriers, and Ethnogenesis. Frontiers in Late Antiquity and the Middle Ages, Turnhout 2005, pp. 91-120.

Yıldız, S.N., "Manuel Komnenos Mavrozomes and His Descendants at the Seljuk Court: The Formation of a Christian Seljuk-Komnenian Elite", in: St. Leder (ed.), Crossroads between Latin Europe and the Near East: Corollaries of the Frankish Presence in the Eastern Mediterranean (12th-14th centuries), Würzburg 2011, pp. 55-80.

Zhivkov, B., Khazaria in the Ninth and Tenth Centuries, Leiden/Boston 2015.

Ziemann, D., Vom Wandervolk zur Großmacht. Die Entstehung Bulgariens im frühen Mittelalter (7.-9. Jahrhundert), Kölner Historische Abhandlungen 43, Cologne/ Weimar/Vienna 2007. 